\title{
42. SILICOFLAGELLATES FROM LEG 120 ON THE KERGUELEN PLATEAU, SOUTHEAST INDIAN OCEAN ${ }^{1}$
}

\author{
Kevin McCartney² and David M. Harwood ${ }^{3}$
}

\begin{abstract}
The biostratigraphic distribution and abundance of Eocene to Pleistocene silicoflagellates is documented from Ocean Drilling Program Leg 120 Holes 747A, 748A, 748B, 749B, and 751A on the Central Kerguelen Plateau. Well-preserved silicoflagellates are reported here from the middle Eocene Dictyocha grandis Zone to the Pleistocene Distephanus speculum speculum Zone. Assemblage diversity and abundance is variable, with many intervals either barren of silicoflagellates or containing only limited numbers.
\end{abstract}

\section{INTRODUCTION}

Twelve holes at five sites on the Central Kerguelen Plateau were drilled by Ocean Drilling Program (ODP) Leg 120 during March and April 1988 (Table 1 and Fig. 1). All sites are south of the present Polar Front and lie within the Antarctic water mass. Leg 120 represents the second half of a two-leg latitudinal transect from the Northern Kerguelen Plateau to the Antarctic margin near Prydz Bay. Leg 119 drilled numerous holes north and south of the Leg 120 sites (Fig. 1).

This report documents the biostratigraphic occurrence and abundance of silicoflagellates from Holes 747A, 748A, 748B, $749 \mathrm{~B}$ and 751A on the Kerguelen Plateau. No individual hole spans the entire interval where silicoflagellates occur, middle Eocene to Pleistocene, but collectively most ages are represented in at least two holes (Figs. 2 and 3). In general, Pliocene to Pleistocene sediments are of diatom ooze or foraminifer diatom ooze, with middle Eocene to upper $\mathrm{Mi}$ ocene sediments of nannofossil ooze or chalk. The exception to this is Site 751, where siliceous microfossils are well represented throughout the Miocene nannofossil-rich intervals below the Pliocene-Pleistocene diatom ooze. Near-continuous recovery in several sites from the upper Oligocene to Pleistocene enables detailed biostratigraphic and paleoceanographic studies, although several hiatuses representing 1-4 m.y. (Fig. 3) are clearly present (see biostratigraphic syntheses of Harwood et al., this volume, and Berggren et al., this volume). The lower range of silicoflagellate recovery corresponds with the occurrence of chert in the lower Oligocene and Eocene. Sparse Upper Cretaceous assemblages are noted in Core 120-748C-47R and Section 120-750B-6W-CC.

Existing literature on silicoflagellate biostratigraphy from previous Deep Sea Drilling Project (DSDP) and ODP legs to the Southern Ocean provides a wealth of information for taxonomic and biostrati-graphic reference. In sequential order of the legs, they include Bukry (1975a, 1975b), Ciesielski (1975), Perch-Nielsen (1975), Hajos and Stradner (1975), Haq and Riley (1976), Busen and Wise (1977), Shaw and Ciesielski (1983), McCartney and Wise (1990), Ciesielski (1991), and Bukry (1991). Silicoflagellate distributions in Antarctic continental shelf sediments are reported in the Ross Sea Embay-

\footnotetext{
${ }^{1}$ Wise, S. W., Jr., Schlich, R., et al., 1992. Proc. ODP, Sci. Results, 120: College Station, TX (Ocean Drilling Program).

2 University of Maine at Presque Isle, Presque Isle, ME 04769, U.S.A.

3 Department of Geology, 214 Bessey Hall, University of NebraskaLincoln, Lincoln, NE 68588-0340, U.S.A.
}

ment by Ling and White (1979), White (1980), Harwood (1986, 1989), and Harwood et al. (1989), and on the Antarctic Peninsula by Harwood (1988).

\section{SAMPLE PREPARATION}

Samples used in this study are from the same samples used for diatom investigation (Harwood and Maruyama, this volume). Raw samples were prepared as smear slides with a $22 \times$ $50 \mathrm{~mm}$ cover slip when diatoms occurred in abundances $>50 \%$ of the microfossils. Lower values of diatom abundance required chemical treatment with $\mathrm{H}_{2} \mathrm{O}_{2}$ and $\mathrm{HCl}$ to concentrate the siliceous fossils, and strewn slides were then prepared after the residues were washed of these chemicals. Where silicoflagellates were abundant, 300 specimens were counted. If silicoflagellates were less abundant, up to an entire slide was examined. The abundance of silicoflagellates varied considerably, with 300 counts reached after only two or three traverses of some slides, whereas other samples were barren or nearly so. To show the general abundance of silicoflagellates, the approximate fraction of the slide examined is recorded in the abundance charts (Tables 2-5). Each tenth of the slide examined represents approximately $1.1 \mathrm{~cm}^{2}$; the relative abundance of any two slides can be obtained by dividing the total count by the area of each slide examined.

Only those fragments representing more than one half of a silicoflagellate were included in the counts. Because the number of teratoid (aberrant) specimens may be an indication of environmental stress, a separate tally was made of these. Aberrant include specimens with fused spines or struts, two struts attaching to a basal side, or distorted basal rings (see McCartney and Loper, 1989, for a discussion on the basic rules of silicoflagellate form). Because the aberrants are often counted among the specific taxa, the number of abberants is not included in the total counts.

Because silicoflagellates typically make up only a small proportion of the siliceous microfossils in a given sediment sample, more time must be spent per slide to obtain useful data. For this reason, the sample interval used in producing Tables $2-5$ is larger than that for the diatom work (Harwood and Maruyama, this volume). However, many additional samples received less detailed analysis to show more precisely the boundaries between zones and better clarify the range of important taxa.

\section{SILICOFLAGELLATE ZONATION}

A number of southern high-latitude silicoflagellate zonations have been proposed in the literature (Bukry, 1975b; 
Table 1. Details of holes drilled during Leg 120.

\begin{tabular}{|c|c|c|c|c|c|}
\hline Hole & Latitude & Longitude & $\begin{array}{c}\text { Water } \\
\text { depth } \\
\text { (m) }\end{array}$ & $\begin{array}{l}\text { Cored } \\
\text { (m) }\end{array}$ & $\begin{array}{c}\text { Recovery } \\
(\%)\end{array}$ \\
\hline $747 \mathrm{~A}$ & $54^{\circ} 48.68^{\prime} \mathrm{S}$ & $76^{\circ} 47.64^{\prime} \mathrm{E}$ & 1695.0 & 256.0 & 88.7 \\
\hline $748 \mathrm{~A}$ & $58^{\circ} 26.45^{\prime} \mathrm{S}$ & $78^{\circ} 58.89^{\prime} \mathrm{E}$ & 1287.5 & 19.0 & 101.3 \\
\hline $748 B$ & $58^{\circ} 26.45^{\prime} \mathrm{S}$ & $78^{\circ} 58.89^{\prime} \mathrm{E}$ & 1290.9 & 225.1 & 84.5 \\
\hline 749B & $58^{\circ} 43.03^{\prime} \mathrm{S}$ & $76^{\circ} 24.45^{\prime} \mathrm{E}$ & 1069.5 & 123.8 & 52.2 \\
\hline $751 \mathrm{~A}$ & $57^{\circ} 43.56^{\prime} \mathrm{S}$ & $79^{\circ} 48.89^{\prime} \mathrm{E}$ & 1633.8 & 166.2 & 98.0 \\
\hline
\end{tabular}

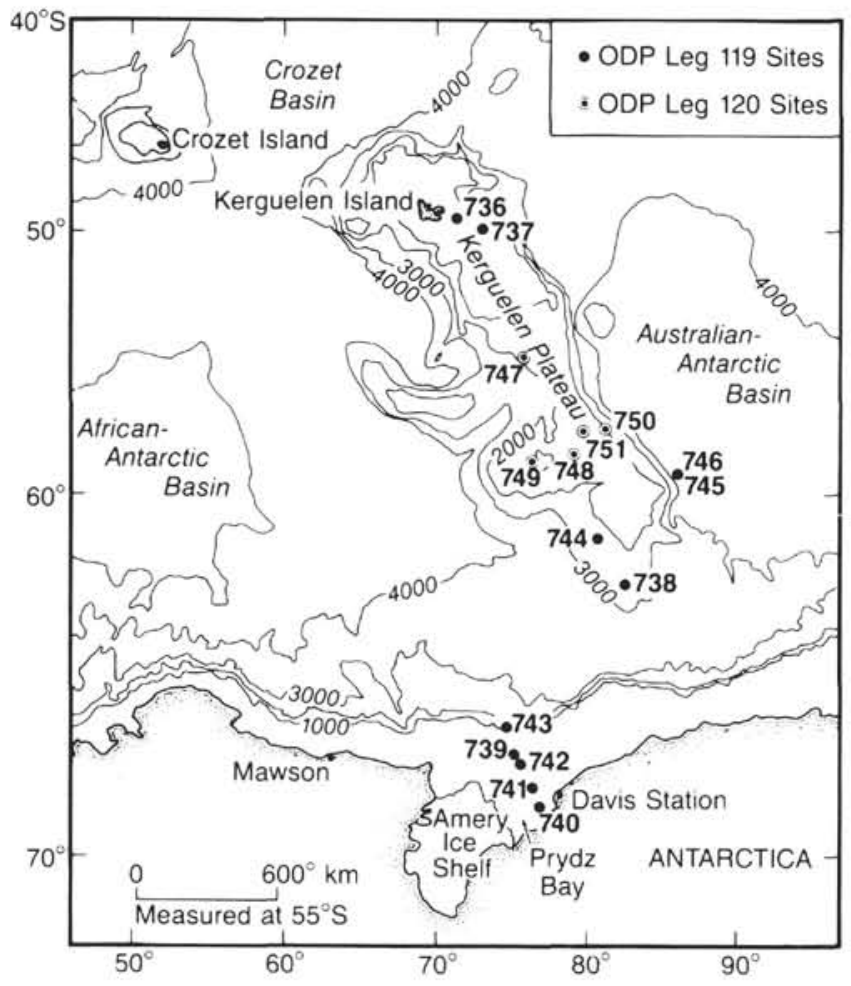

Figure 1. Location map showing sites drilled during Leg 120. Circles with dots refer to sites drilled during Leg 120 and circles without dots refer to Leg 119 sites.

Ciesielski, 1975; Martini and Müller, 1976; Shaw and Ciesielski, 1983; Ciesielski, 1991). Two of these zonations are modified and used in this study (Fig. 4). The Bukry (1975b) zonation, as modified by McCartney and Wise (1990), is used from the Pleistocene to the middle Miocene Corbisema triacantha Zone. The Ciesielski (1991) zonation is used for older sediments, with two zones proposed by Shaw and Ciesielski (1983) included. Two zones proposed by Ciesielski (1991), the Naviculopsis pandalata and Bachmannocena vetula zones, were not used in this study because the nominative taxa were not readily discernible and are believed here to be ecophenotypic rather than biostratigraphic indicators. The occurrence of silicoflagellates in Leg 120 cores is shown in Figure 5. The stratigraphic level of the first and last datums shown in Figure 5 in some cases do not correspond to intervals listed in the distribution tables (Tables 2-5) because of the closer sample spacing used to determine these datums than is reported in the distribution tables.

\section{Dictyocha grandis Partial Range Zone}

Definition. Interval from the first occurrence (FO) of Dictyocha stelliformis at the base of the zone up to the last occurrence (LO) of D. grandis.
Author. Shaw and Ciesielski (1983), emended by Ciesielski (1991).

Common species. Dictyocha grandis and Naviculopsis constricta.

Remarks. This zone was observed in Holes 748B and 749B. No deformed naviculopsids ( $N$. pandalata of Ciesielski, 1991) were found. D. stelliformis occurs in the lower portion of the zone and has been defined as a subzone by Ciesielski (1991).

\section{Bachmannocena paulschulzii Interval Zone}

Definition. Interval from the LO of Dictyocha grandis at the zone base up to the first abundant occurrence of Naviculopsis trispinosa. Authors. Shaw, in Shaw and Ciesielski (1983), emended herein.

Common species. Bachmannocena paulschulzii, Naviculopsis constricta, N. eobiapiculata, and Distephanus crux.

Remarks. This zone was found in the upper Eocene of Holes 748B and $749 \mathrm{~B}$. The zone was originally described in Shaw and Ciesielski (1983) as the Mesocena occidentalis Zone and was redefined by Ciesielski (1991) as the B. paulschulzii Zone between the last abundant appearance datum of $N$. constricta up to the first abundance appearance datum of $N$. trispinosa. We emend the lower boundary to be recognized by the last occurrence of $D$. grandis rather than $N$. constricta.

\section{Naviculopsis trispinosa Partial Range Zone}

Definition. Interval from the first abundant occurrence of Naviculopsis trispinosa at the zone base, up to the FO of Corbisema archangelskiana.

Author. Shaw, in Shaw and Ciesielski (1983), emended by Ciesielski (1991), further emended herein.

Common species. Bachmannocena apiculata, Corbisema hastata, Dictyocha deflandrei, Distephanus crux, and Naviculopsis biapiculata.

Remarks. The top of this zone was defined by Shaw (in Shaw and Ciesielski, 1983) as the lowest consistent occurrence of Dictyocha deflandrei, but Ciesielski (1991) reduced this datum to a secondary datum level because of apparent sensitivity of this taxon to changes in water temperature. We think that the FO of $C$. archangelskiana is a more widely applicable top for this zone. The zone occurs in the lower Oligocene of Holes 748B and 749B.

\section{Corbisema archangelskiana Range Zone}

Definition. Range of Corbisema archangelskiana.

Author. Ciesielski, in Shaw and Ciesielski (1983).

Common species. Distephanus crux, Distephanus rauppi, Naviculopsis biapiculata, and, in Hole 749B, Dictyocha frenguellii.

Remarks. In this study, the first common occurrence of Distephanus speculum speculum was in this zone, which was found in the upper Oligocene of Holes 748B and 749B.

\section{Naviculopsis biapiculata Partial Range Zone}

Definition. Interval from the LO of Corbisema archangelskiana at the zone base, up to the LO of Naviculopsis biapiculata.

Author. Bukry (1975b), emended by Shaw and Ciesielski (1983).

Common species. Bachmannocena apiculata, Distephanus crux, multiwindowed variants of Distephanus speculum speculum, and Naviculopsis eobiapiculata.

Remarks. This zone was recognized in the upper Oligocene of Holes 748B and 749B.

\section{Distephanus raupii Partial Range Zone}

Definition. Interval from the last occurrence of Naviculopsis biapiculata at the zone base, up to the last occurrence of Distephanus raupii.

Author. Ciesielski (1991).

Remarks. This zone was not identified in this study. Its absence in Hole 748B is explained by an hiatus in Core $120-748 \mathrm{~B}-6 \mathrm{H}$.

\section{Distephanus raupii-Corbisema triacanthaInterval Zone}

Definition. Interval from the LO of Distephanus raupii at the zone base, up to the first common occurrence of Corbisema triacantha.

Author. Ciesielski (1991).

Remarks. This zone was not identified in this study. Its absence in Hole $748 \mathrm{~B}$ is explained by an hiatus in Core $120-748 \mathrm{~B}-6 \mathrm{H}$. 

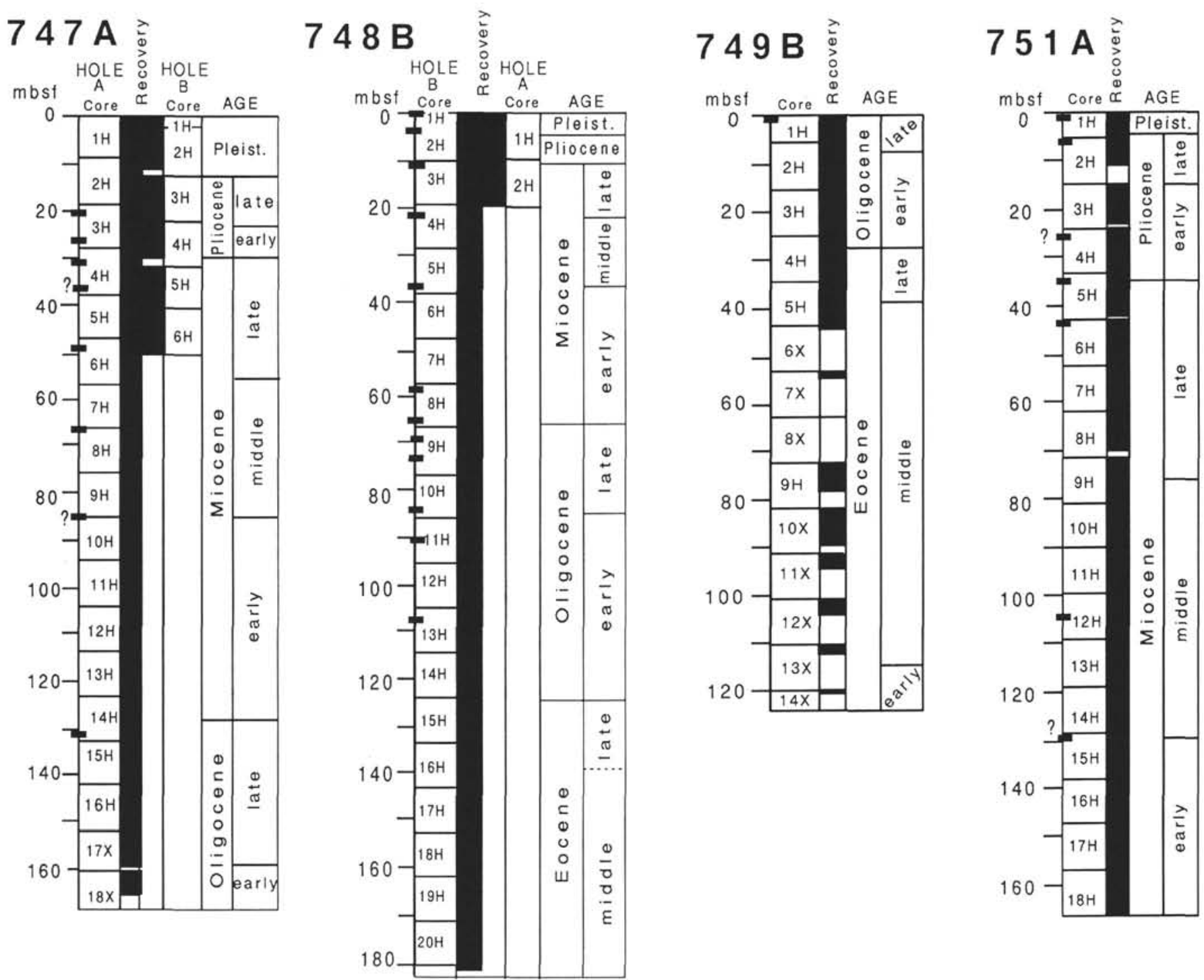

Figure 2. Intervals of silicoflagellate occurrence shown in relation to age, core depth, and sediment recovery.

Corbisema triacantha Partial Range Zone

Definition. Interval from the first abundant occurrence of Corbisema triacantha at the zone base, up to the LO of $C$. triacantha.

Author. Martini (1971).

Common species. Distephanus crux, Ds. speculum speculum, and Ds. speculum pentagonus.

Remarks. This zone was found in the middle Miocene of Hole 751A.

\section{Distephanus longispinus Interval Zone}

Definition. Interval from the LO of Corbisema triacantha at the zone base, up to the first common occurrence of the pseudofibula plexus.

Author. Bukry and Foster (1973), modified by McCartney and Wise (1990).

Common species. Distephanus crux, Ds. speculum speculum, and Ds. speculum pentagonus.

Remarks. This zone was found in the middle and upper Miocene of Hole 751A.

The "pseudofibula plexus" Range Zone

Definition. Interval between the FO and last common occurrence of members of the pseudofibula plexus.

Author. Bukry (1973), modified by McCartney and Wise (1990).

Common species. Distephanus speculum speculum with an apical structure that does not include a ring. Bachmannocena circulus and $B$. diodon may also be abundant, but their abundance is usually not consistent throughout the interval.

Remarks. This zone is found in Holes $747 \mathrm{~A}$ and $751 \mathrm{~A}$, and pseudofibulid variants are scarce in Hole 749B. Members of the pseudofibula plexus are abundant in Hole 751A, but they are not as predominant as in ODP Leg 113 (McCartney and Wise, 1990).

\section{Distephanus speculum speculum Zone}

Definition. Interval from the last abundant occurrence of the pseudofibula plexus at the zone base, up to the first common occurrence of Distephanus octonarius.

Author. Bukry (1973), emended by Bukry (1975b) and McCartney and Wise (1990).

Common species. Distephanus boliviensis and Ds. speculum pentagonus. This zone was found in Holes 747A and 751A.

\section{SITE SUMMARIES}

\section{Site 747}

Site 747 (Table 2) was drilled on a broad terrace located in the transition zone between the Northern and Southern Kerguelen Plateaus (Fig. 1), approximately $500 \mathrm{~km}$ south of the Polar Front $\left(54^{\circ} 49^{\prime} \mathrm{S}\right.$ and $76^{\circ} 49^{\prime} \mathrm{E}$; water depth, $\left.1697.7 \mathrm{~m}\right)$. A 


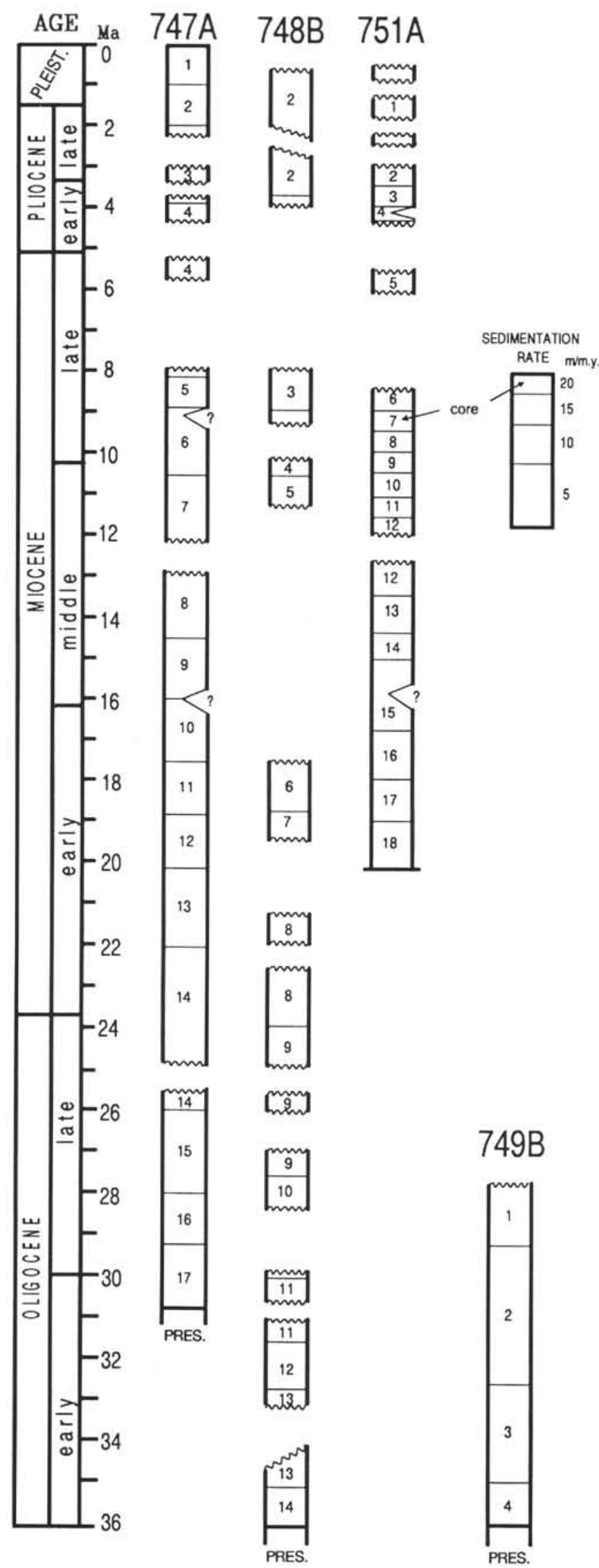

Figure 3. Simplified Cenozoic stratigraphy for Leg 120 sites plotted to a vertical age scale, showing position of key hiatuses at each site. pelagic sedimentary section spanning the lower Santonian through upper Pleistocene (296.5 m thick) and underlying basalt $(53.9 \mathrm{~m})$ was recovered in three holes drilled at Site 747. Objectives of this site were (1) to determine the nature and age of basement of this northern site for comparison with other sites on the Southern Kerguelen Plateau and (2) to study the paleoceanographic history of the region and trace migrations of the Polar Front through time.

The sedimentary section recovered at Site 747 includes approximately $33 \mathrm{~m}$ of upper Pleistocene to upper Miocene foraminifer diatom ooze (Unit I). Ice-rafted debris and dropstones are prevalent only in the upper $20 \mathrm{~m}$. This overlies Miocene to lower Paleocene nannofossil ooze and chalk that continue down to 181.45 mbsf. Lower Danian to Santonian sediments (Units II to IV) continue from this level down to $296.5 \mathrm{~m}$ and are underlain by basalt flows to $350.5 \mathrm{mbsf}$. Sedimentation rates are slow from the Oligocene to the Holocene $(5-10 \mathrm{~m} / \mathrm{m} . \mathrm{y})$. Several short hiatuses are noted throughout the Neogene and upper Paleogene (Harwood et al., this volume) (Fig. 3).

Silicoflagellates were generally not found to be abundant in Hole 747A, except in Samples 120-747A-2H-4, 47-48 cm, and $-3 \mathrm{H}-2,47-48 \mathrm{~cm}$, which were veritable silicoflagellate oozes. Pleistocene and Pliocene silicoflagellate assemblages are dominated by Distephanus speculum speculum.

The pseudofibula plexus, usually shown by abundant and dominant morphologies of Distephanus speculum speculum that lack apical rings, is barely present in Hole 747A. The plexus formed a distinctive horizon in a number of holes drilled during Leg 113 (see McCartney and Wise, 1990) and is similarly distinctive in a four-section interval in Hole 751A. Two pseudofibulid specimens are found in Sample 120-747$4 \mathrm{H}-4,47-48 \mathrm{~cm}$, which outnumber the single specimen of apical-ringed Distephanus speculum speculum, and is interpreted as a part of the plexus proper, but the remainder of the plexus appears to be removed by a hiatus.

Silicoflagellates were generally not abundant below the Pliocene. Silicoflagellates are poorly represented in Cores $120-747 \mathrm{~A}-8 \mathrm{H}$ through $-12 \mathrm{H}$, preventing the identification of silicoflagellate zones for this interval. Bachmannocena hexalitha and Paradictyocha dumitricae were noted in Section $120-747 \mathrm{~A}-7 \mathrm{H}-\mathrm{CC}$, but were not found in the counted samples. The Ds. raupii Zone is apparently missing in a hiatus because the highest occurrence of the nominative taxon in Sample 120-747A-15H-2, 47-48 cm, is coincident with the highest occurrence of Naviculopsis biapiculata, which identifies the base of the Ds. raupii Zone. The base of the underlying Naviculopsis biapiculata Zone and the top of the $C$. archangelskiana Zone is noted in Sample 120-747A-17H-4, 47-48 $\mathrm{cm}$. Bachmannocena occidentalis is present in Sample 120747A-17H-CC.

\section{Site 748}

Site 748 (Table 3) is located in the western part of the Raggatt Basin on the Southern Kerguelen Plateau $\left(58^{\circ} 27^{\prime} \mathrm{S}\right.$, $78^{\circ} 59^{\prime} \mathrm{E}$; water depth, $1290 \mathrm{~m}$ ), approximately $900 \mathrm{~km}$ south of the Polar Front. One objective of this site was to recover an expanded section of Paleogene and Cretaceous sediments and basement to decipher the tectonic, geologic, and paleoceanographic history of the Southern Kerguelen Plateau. Two holes were drilled at this site to a total penetration depth of $935 \mathrm{~m}$. Approximately $15 \mathrm{~m}$ of Pliocene-Pleistocene diatom ooze with radiolarian and foraminifer enriched intervals (Unit I) overlay upper Miocene to upper Paleocene nannofossil ooze, chalk, and chert (Unit II) that continues to 397.4 mbsf. Upper Cretaceous glauconitic sediments (Unit III) continue down to 898.8 mbsf where basalt was cored to 935 mbsf. The sili- 


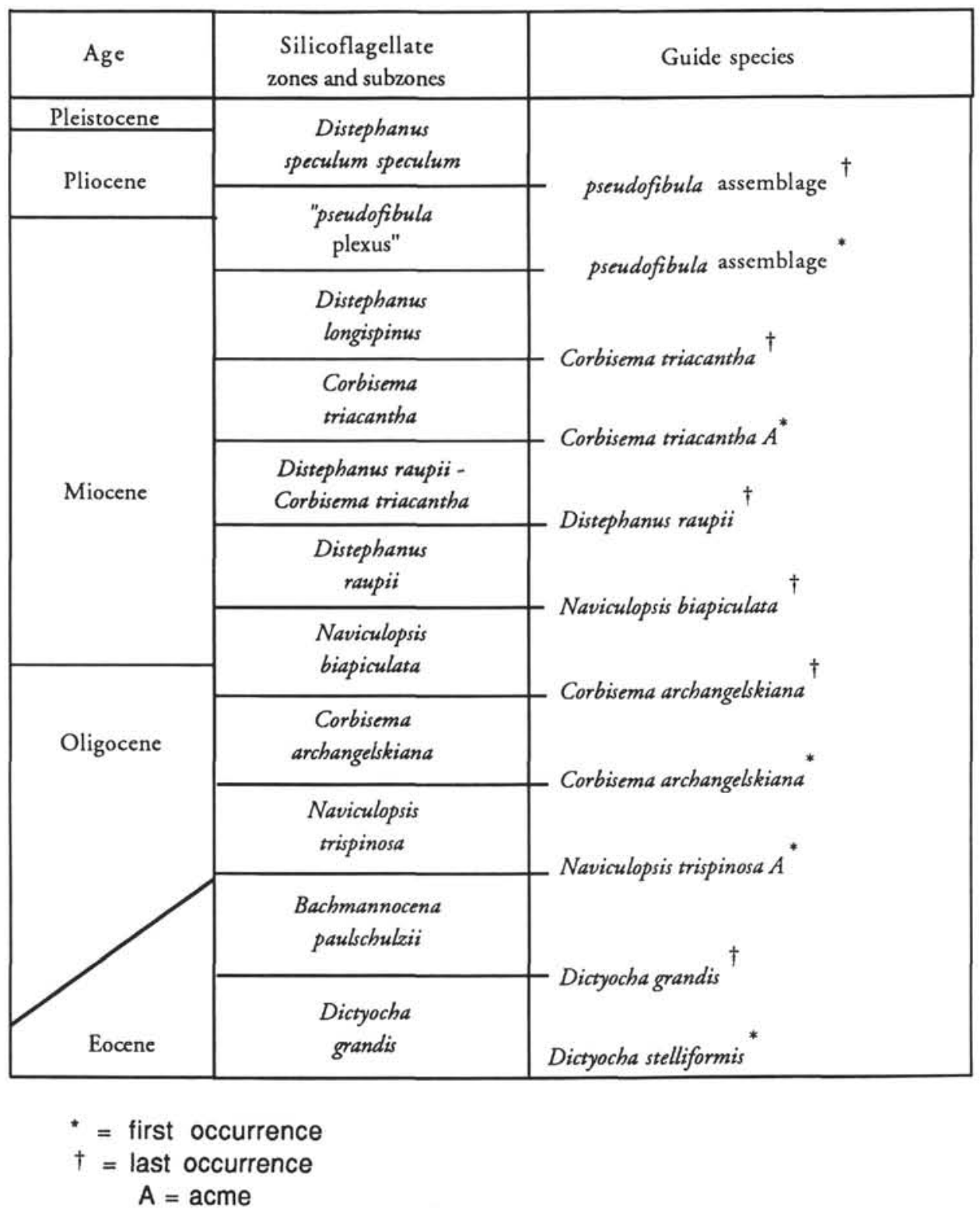

Figure 4. Silicoflagellate zonation used for Leg 120.

coflagellate occurrence is sporadic in the upper $180 \mathrm{~m}$ at Hole $748 \mathrm{~B}$, with assemblages noted from the middle Eocene to Pleistocene. Full recovery in this interval provides a good biosiliceous and calcareous reference section for the southern high latitudes that is calibrated with good paleomagnetic control. However, hiatuses are noted throughout the cored sequence, some representing as much as $4 \mathrm{~m} . \mathrm{y}$. (Fig. 3). Average sedimentation rates for the Pleistocene to upper Oligocene increased downward from 4 to $5 \mathrm{~m} / \mathrm{m}$.y. with rates approaching $6.5 \mathrm{~m} / \mathrm{m}$.y. for the lower Oligocene to middle Eocene.

As at Site 747, silicoflagellates in Pliocene and uppermost Miocene intervals are sporadically abundant and dominated by Distephanus speculum speculum with minor Distephanus speculum pentagonus and Dictyocha messanensis.

Several studies have used the relative ratios of two silicoflagellate genera to deduce a relative temperature index (Ciesielski and Weaver, 1974), with increased abundance of Dictyocha representing warmer oceanic conditions, and per- haps southward migrations of the Polar Front. Today, Dictyocha is not found south of the Polar Front (Pichon et al., 1987). We do not extrapolate temperatures from these data in this paper, but we note several "warmer" intervals in the late Neogene. Dictyocha spp. first appears with abundances roughly twice that of Distephanus spp. in lower Pliocene Sample $120-748$ B-2H-6, $81-82 \mathrm{~cm}$. This represents only a brief increase in Dictyocha relative to Distephanus because Distephanus is dominant in Samples 120-748B-2H-4, 83-84 $\mathrm{cm}$, and $-3 \mathrm{H}-1,40-41 \mathrm{~cm}$, which lie above and below the Dictyocha dominated sample. A similar Dictyocha-event occurred during the middle late Miocene, as noted in Sample $120-748 \mathrm{~B}-3 \mathrm{H}-6,47-48 \mathrm{~cm}$, and $-3 \mathrm{H}-\mathrm{CC}$ by near-equal numbers of Dictyocha and Distephanus. Dictyocha predominates in Sample 120-748B-4H-6, 47-48 cm. Sites 747, 748, and 751 and other sites on Leg 119 are ideal for this sort of paleoceanographic study because of their position relative to the Polar Front and the numerous cores on a long latitudinal transect (Fig. 1). Many other Dictyocha events are noted in these 


\begin{tabular}{|c|c|c|c|c|c|c|c|}
\hline \multirow[t]{2}{*}{ AGE } & \multirow[t]{2}{*}{ ZONE } & \multicolumn{6}{|c|}{ HOLES } \\
\hline & & $747 \mathrm{~A}$ & $747 \mathrm{~B}$ & $748 \mathrm{~B}$ & $749 B$ & $750 \mathrm{~A}$ & $751 \mathrm{~A}$ \\
\hline \multirow{2}{*}{$\frac{\text { PLEIST. }}{\text { PLIOCENE }}$} & $\begin{array}{l}\text { Distephanus } \\
\text { speculum speculum }\end{array}$ & $\begin{array}{c}1 \mathrm{H}-6 \\
\text { to } \\
4 \mathrm{H}-3\end{array}$ & $\begin{array}{c}1 \mathrm{H}-4 \\
\text { to } \\
2 \mathrm{H}-4\end{array}$ & $\begin{array}{c}2 \mathrm{H}-4 \\
\text { to } \\
3 \mathrm{H}-1\end{array}$ & 31 & $1 R-1$ & $\begin{array}{c}1 \mathrm{H}-1 \\
10 \\
5 \mathrm{H}-2\end{array}$ \\
\hline & $\begin{array}{l}\text { pseudofibula } \\
\text { plexus }\end{array}$ & $4 \mathrm{H}-4$ & & & & & $\begin{array}{l}5 \mathrm{H}-2 \\
\text { to } \\
6 \mathrm{H}-1\end{array}$ \\
\hline \multirow{4}{*}{ MIOCENE } & $\begin{array}{l}\text { Distephanus } \\
\text { longispinus }\end{array}$ & & & & & & $\begin{array}{c}6 \mathrm{H}-2 \\
\text { to } \\
12 \mathrm{H}-4\end{array}$ \\
\hline & $\begin{array}{l}\text { Corbisema } \\
\text { triacantha }\end{array}$ & & & & & & $\begin{array}{c}13 \mathrm{H}-4 \\
\text { to } \\
18 \mathrm{H}-5 \\
\end{array}$ \\
\hline & $\begin{array}{l}\text { Distephanus raupii - } \\
\text { Corbisema triacantha }\end{array}$ & & & & & & \\
\hline & $\begin{array}{l}\text { Distephanus } \\
\text { raupii }\end{array}$ & & & wa & & & \\
\hline \multirow{3}{*}{ OLIGOCENE } & $\begin{array}{l}\text { Naviculopsis } \\
\text { biapiculata }\end{array}$ & $\begin{array}{c}13 \mathrm{H}-2 \\
\text { to } \\
16 \mathrm{CC}\end{array}$ & & $\begin{array}{c}7 \mathrm{H}-1 \\
\text { to } \\
9 \mathrm{H}-3\end{array}$ & & & \\
\hline & $\begin{array}{c}\text { Corbisema } \\
\text { archangelskiana }\end{array}$ & \begin{tabular}{|c|}
$17 \mathrm{H}-1$ \\
to \\
$18 \mathrm{X}-2$ \\
\end{tabular} & & \begin{tabular}{|c|}
$9 H-4$ \\
$t 0$ \\
$11 H-3$ \\
\end{tabular} & $\begin{array}{l}1 \mathrm{H}-2 \\
\text { to } \\
2 \mathrm{H}-2 \\
\end{array}$ & & \\
\hline & $\begin{array}{l}\text { Naviculopsis } \\
\text { trispinosa }\end{array}$ & & & $\begin{array}{c}11 \mathrm{H}-4 \\
\text { to } \\
14 \mathrm{H}-1\end{array}$ & $\begin{array}{l}2 \mathrm{H}-3 \\
\text { to } \\
3 \mathrm{H}-4\end{array}$ & & the \\
\hline \multirow{2}{*}{ EOCENE } & $\begin{array}{l}\text { Bachmannocena } \\
\text { paulschulzii }\end{array}$ & & & \begin{tabular}{|c|}
$14 \mathrm{H}-2$ \\
to \\
$17 \mathrm{H}-3$ \\
\end{tabular} & $\begin{array}{c}3 \mathrm{H}-5 \\
10 \\
5 \mathrm{H}-2\end{array}$ & & \\
\hline & $\begin{array}{l}\text { Dictyocha } \\
\text { grandis }\end{array}$ & & & $\begin{array}{r}17 \mathrm{H}-4 \\
\text { to } \\
20 \mathrm{CC}\end{array}$ & $\begin{array}{c}5 \mathrm{H}-4 \\
\text { to } \\
9 \mathrm{H}-1\end{array}$ & $\begin{array}{c}1 R \cdot 3 \\
\text { to } \\
1 R^{\circ} C C\end{array}$ & \\
\hline
\end{tabular}

Figure 5. Silicoflagellate zones found in Leg 120.

sediments, but they are not recorded in this study because of limited sample spacing.

Silicoflagellates Bachmannocena diodon and $B$. circulus were noted in Sample 120-748B-3H-1, 129-130 cm, suggesting the upper Miocene $B$. diodon/B. circulus Zone as applied by Shaw and Ciesielski (1983). The presence of silicoflagellates Paradictyocha apiculata and $B$. circulus, in the absence of $B$. diodon in Sample 120-748B-5H-CC, indicates the middle to upper Miocene $M$. circulus Zone, as defined by Shaw and Ciesielski (1983). The pseudofibula plexus was not found, even though the site is close to Hole $751 \mathrm{~A}$, which has a distinct pseudofibulid acme; this evidence suggests the presence of a hiatus from the lower Pliocene to upper Miocene (Fig. 3).

A hiatus noted in the upper portion of Core $120-748 \mathrm{~B}-6 \mathrm{H}$ apparently removed portions of the Ds. raupii and $N$. biapiculata zones. The top and base of the $C$. archangelski Zone is defined by the total range of this species between Samples $120-748 \mathrm{~B}-9 \mathrm{H}-4,47-48 \mathrm{~cm}$, and $-11 \mathrm{H}-4,47-48 \mathrm{~cm}$, respectively. The base of the underlying $N$. trispinosa Zone is identified by the lowest occurrence of $N$. trispinosa in Sample $120-748 \mathrm{~B}-14 \mathrm{H}-1,47-48 \mathrm{~cm}$. This is coincident (given the broad sample spacing) with the highest occurrence of $N$. constricta, implying either the absence or the limited stratigraphic extent of the underlying $B$. paulshulzii Zone that is defined by these two datums. The lower Oligocene to upper Eocene $N$. constricta-B. paulshulzii and $N$. pandalata zones are not recognized in this study because of limited silicoflagellate occurrence in these intervals. The presence of Hannites quadria in Sample 120-748B-15H-CC suggests the presence of upper Eocene sediments at this level. Silicoflagellates are poorly represented in Cores $120-748 \mathrm{~B}-16 \mathrm{H}$ to $-18 \mathrm{H}$ because of poor preservation, but the robust silicoflagellate Dictyocha grandis is noted in the lower portions of Core $120-748 \mathrm{~B}-17 \mathrm{H}$ and throughout Core $120-748 \mathrm{~B}-18 \mathrm{H}$, indicating a position within the middle Eocene Dictyocha grandis Zone. The presence of Bachmannocena apiculata in this interval indicates a position within the upper portion of the $D$. grandis Zone (i.e., the B. apiculata Subzone; see Shaw and Ciesielski, 1983; Ciesielski, 1991).

\section{Site 749}

Site 749 (Table 4) is located on the western flank of the Banzare Bank on the southern Kerguelen Plateau $\left(58^{\circ} 43^{\prime} \mathrm{S}\right.$, $76^{\circ} 25^{\prime} \mathrm{E}$; water depth, $1069.5 \mathrm{~m}$ ). The objective of this site was to recover a thick section of basement rocks from the Southern Kerguelen Plateau. Approximately $200 \mathrm{~m}$ of upper Oligocene to lower Eocene nannofossil ooze with chert, chalk, and porcellanite was drilled, with $100 \%$ recovery of the upper $43.8 \mathrm{mbsf}$ as well as recovery of $23.1 \mathrm{~m}$ of basalt to a depth of $249.5 \mathrm{mbsf}$. A thin layer of mixed upper Pliocene and lower Pleistocene diatom ooze with foraminifers and ice-rafted debris (Unit I) lies unconformably on the Paleogene nannofossil ooze (Unit II) in Holes 749A and 749B.

Silicoflagellates are present in the Pliocene-Pleistocene intervals of Holes $749 \mathrm{~A}$ and $749 \mathrm{~B}$, but they are not documented here because of the limited recovery of this age. Oligocene silicoflagellates are well represented in the upper three cores of Hole 749B representing portions of the Naviculopsis biapiculata through Naviculopsis constricta-B. paulshulzii zones. The base of the $N$. biapiculata Zone is identified by the highest occurrence of Corbisema archangelskiana between Samples 120-749B-1H-3, 110-112 cm, and $-2 \mathrm{H}-2,110-112 \mathrm{~cm}$. The $C$. archangelskiana Zone is recognized in the latter sample, with the base of this zone occurring between Samples 120-749B-2H-2, 110-112 cm, and -2H-5, $110-112 \mathrm{~cm}$. The underlying $N$. trispinosa Zone was also identified in only one sample.

The Bachmannocena paulshulzii Zone is not recognized here, but the underlying $N$. constricta-B. paulshulzii Zone is identified between Samples 120-749B-3H-2, 110-112 cm, and $-3 \mathrm{H}-5,110-112 \mathrm{~cm}$, below which sediments are barren of silicoflagellates until the middle Eocene where a portion of the Dictyocha grandis Zone is noted in Samples 120-749B-5H-4, $110-112 \mathrm{~cm}$, and -9H-CC. Silicoflagellates were not encountered below Sample 120-749B-9H-CC.

\section{Site 751}

Site 751 (Table 5) is located in the central part of the Raggatt Basin in the Southern Kerguelen Plateau $\left(57^{\circ} 44^{\prime} \mathrm{S}\right.$, $70^{\circ} 48^{\prime} \mathrm{E}$; water depth, $1633.8 \mathrm{~m}$ ). The objective of drilling Site 751 was to recover a high-resolution Neogene and Paleogene stratigraphic section that was deposited above the calcite compensation depth (CCD), but south of the Polar Front. A single hole using the advanced hydraulic piston corer (APC) drilled a $166.2-\mathrm{m}$ section of upper Pleistocene through middle lower Miocene mixed biosiliceous and calcareous ooze. Recovery through this interval was $98 \%$, and sedimentation rates varied between 10 and $30 \mathrm{~m} / \mathrm{m} . y$. during the early Miocene to early Pliocene and early Pleistocene. Average rates may be lower than this because shipboard studies identified the presence of several hiatuses (Fig. 3; see Harwood et al., this volume).

Upper Pleistocene to lower Pliocene sediments of Unit I $(0-40.1 \mathrm{mbsf})$ are diatom ooze with minor ice-rafted debris, foraminifers, volcanic ash, and porcellanite. Lower Pliocene to middle lower Miocene sediments of Unit II (40.1-166.2 mbsf) are diatom nannofossil ooze, with diatoms and nannofossils alternating as the dominant constituent.

Silicoflagellates are present throughout the entire middle lower Miocene to middle Pleistocene section recovered in Hole $751 \mathrm{~A}$, but there is considerable variation in abundance. 
Table 2. Abundance of silicoflagellates, Hole 747A.

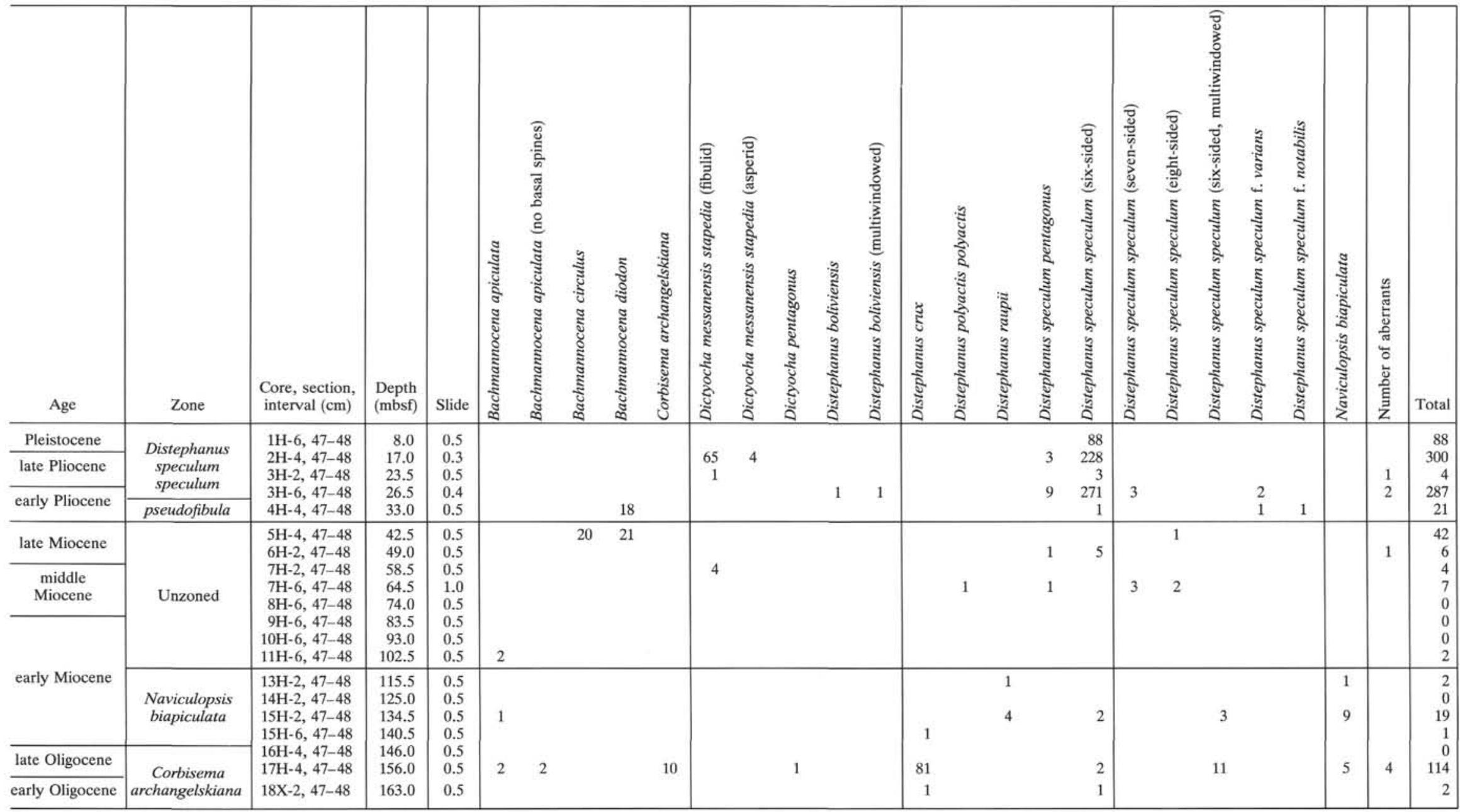

Note: Specimens are recorded as total number found for amount of $22 \times 50 \mathrm{~mm}$ slide examined. 
Table 3. Abundance of silicoflagellates, Holes 748A and 748B.

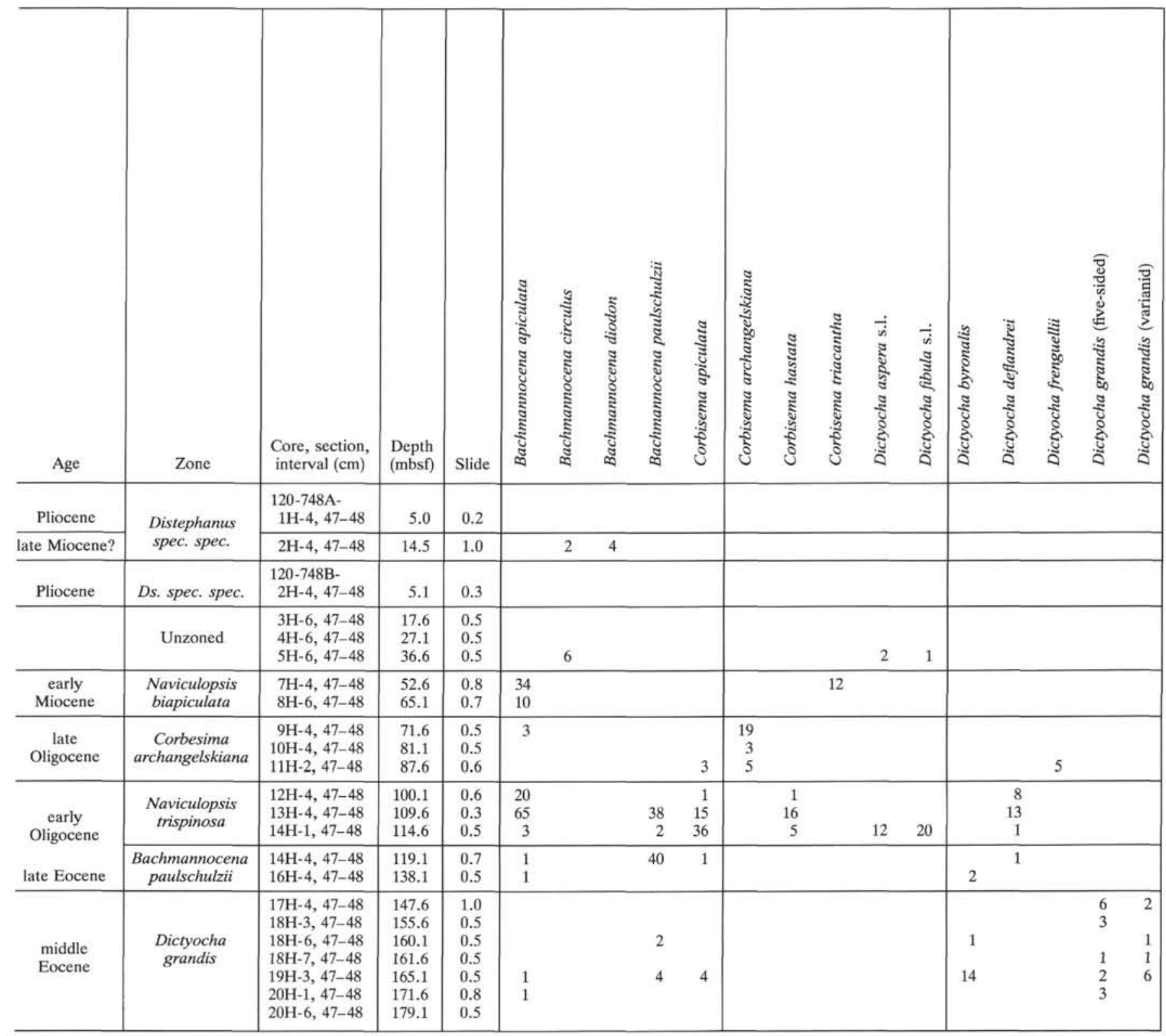

The Distephanus speculum group and Ds. boliviensis dominate the Pliocene and Pleistocene, with Dictyocha spp. abundant at various levels. A large proportion of the Ds. boliviensis are multiwindowed in Sample 120-751A-3H-1, 10-11 cm; work by McCartney and Loper (1989) suggests that such morphologies indicate environmental conditions in which the minimal apical area, and presumably surface tension, are important to the silicoflagellate organism.

The "pseudofibula plexus"' (McCartney and Wise, 1990) is well represented in the interval between Samples 120-751A$6 \mathrm{H}-1,10-11 \mathrm{~cm}$, and $-5 \mathrm{H}-3,10-11 \mathrm{~cm}$. The lower and upper boundaries of the pseudofibula plexus Zone (McCartney and Wise, 1990) are defined by the lowest and highest common occurrence of this assemblage. The base of the underlying Distephanus longispinus Zone of (Bukry and Foster, 1973, addendum) occurs somewhere between Samples 120-751A$13 \mathrm{H}-4,10-11 \mathrm{~cm}$, and $-15 \mathrm{H}-5,10-11 \mathrm{~cm}$, and is poorly defined because of the sporadic occurrence of Corbisema triacantha, the highest occurrence of which defines this boundary, within this interval. The Corbisema triacantha Zone continues downward from Sample 120-751A-16H-4, 10-11 cm, where the nominative species has its highest consistent occurrence, to the base of the hole.

\section{SYSTEMATIC PALEONTOLOGY}

The synonymies include only the first description and, if needed, a recent reference that has a more complete taxonomy or clarifies recent modification.

We acknowledge the problems associated with silicoflagellate taxonomy based on simple morphological characters that may be influenced by environmental controls. Many silicoflagellate morphologies, presently treated as distinct, may be the same taxon. We are faced with the decision to classify them from an evolutionary/genotypic view of taxonomy (lumping) or through an ecological/phenotypic approach (splitting). Although the latter may have greater application to 


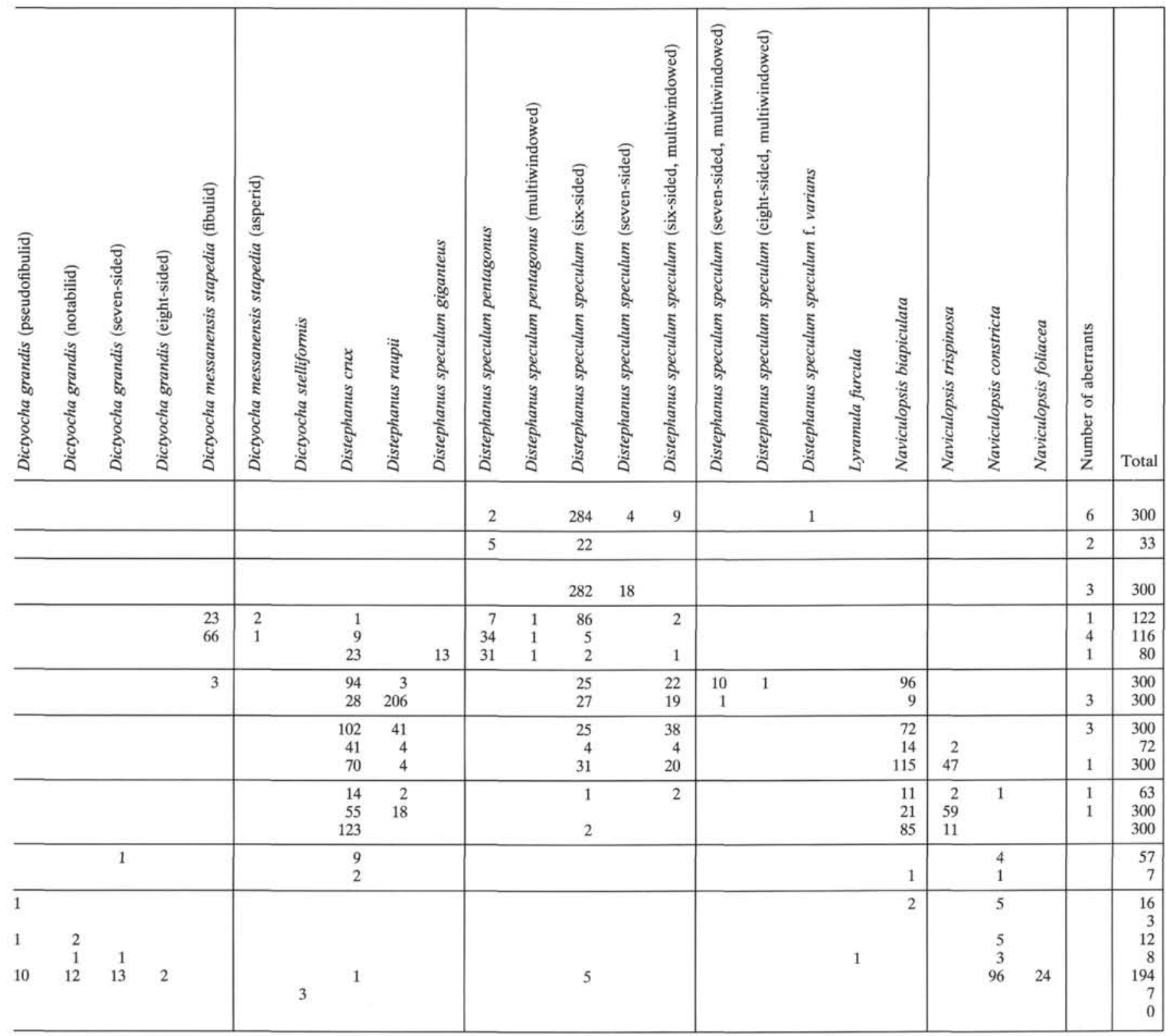

Note: Specimens are recorded as total number found for amount of $22 \times 50 \mathrm{~mm}$ slide examined.

geological, biostratigraphic, and paleoenvironmental problems because of the greater amount of information recorded, it may eventually become cumbersome and unmanageable. Because students of silicoflagellates have these different views of taxonomy, largely dependent on the questions being asked, a wide range of splitting and lumping is tolerated by most workers. This paper cannot address this issue, if it can be resolved at all. Taxonomy is an art and we are all painters. To avoid complicating this situation further by offering new names and combinations, in this paper we adhere to existing concepts of taxa and favor broad morphological groups.

Genus BACHMANNOCENA Locker, 1974, emend. Bukry, 1987

Bachmannocena apiculata (Schulz) Bukry

(Plate 1, Fig. 9)

Mesocena oamaruensis apiculata Schulz, 1928, p. 240, fig. 11.
Mesocena apiculata (Schulz), Ling, 1972, p. 173, pl. 28, figs. 2-4; Shaw and Ciesielski, 1983, p. 714, pl. 12, figs. 1-7.

Bachmannocena apiculata (Schulz) Bukry, 1987, pp. 403-404; McCartney and Wise, 1990, pl. 2, figs. 6-10.

Remarks. This three-sided silicoflagellate has considerable variability, particularly in the shape of the basal ring (see McCartney and Wise, 1990). Following Bukry (1987), the taxon is not subdivided into multiple subspecies because the morphologies occur together and do not appear to have biostratigraphic significance.

\section{Bachmannocena circulus (Ehrenberg) Bukry}

(Plate 2, Figs. 1-2)

Mesocena circulus (Ehrenberg) Ehrenberg, 1844, p. 65.

Bachmannocena circulus (Ehrenberg) Bukry, 1987, p. 404.

Remarks. This taxon occurs sporadically in the Eocene, Oligocene, and middle Miocene of Hole 748B, and also in the upper Miocene of Hole 747A. The species concept used for this taxon is a broad one as 
Table 4. Abundance of silicoflagellates, Hole 749B.

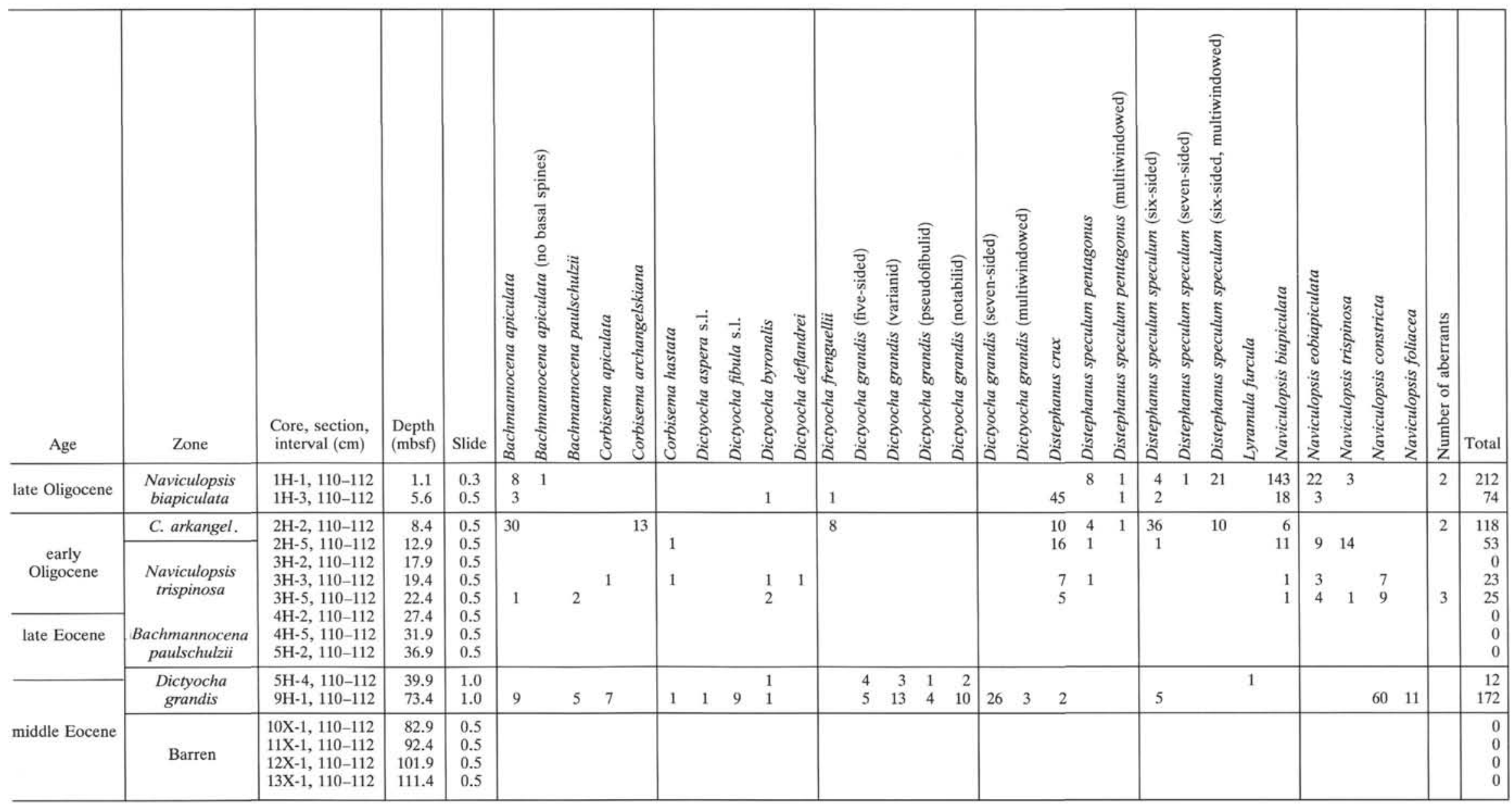

Note: Specimens are recorded as total number found for amount of $22 \times 50 \mathrm{~mm}$ slide examined. 
there is considerable variation in the size of the ring and the number of spines. This taxon appears to be opportunistic as it is very abundant in taxa that contain few other taxa and it does not occur consistently in a majority of the samples that are within its geologic range.

\section{Bachmannocena diodon (Ehrenberg) Bukry}

Mesocena diodon Ehrenberg, 1844, p. 71, 84; Schulz, 1928, p. 236, figs. 1a-b.

Bachmannocena diodon (Ehrenberg) Bukry, 1987, p. 404.

Remarks. Members of this taxon occur in the upper Miocene or upper Pliocene of Holes 747A, 748A, and 751A. In some cases, such as in Sample 120-751A-4H-4, 10-11 cm, the size was fairly small (50 $\mathrm{mm})$.

\section{Bachmannocena hexalitha (Bukry) Bukry}

Mesocena hexalitha Bukry, 1981, p. 547, pl. 5, figs. 5-10.

Bachmannocena hexalitha Bukry, 1987, p. 404.

Remarks. This taxon was encountered only during shipboard work in Sample 120-747A-7H-CC.

\section{Bachmannocena quadrangula Ehrenberg ex Haeckel} (Plate 2, Fig. 5)

Mesocena quadrangula Ehrenberg ex Haeckel 1887, p. 1556, Lemmermann, 1901, pl. 10, figs. 5-7, fide Loeblich et al., 1968, p. 57.

Mesocena quadrangula Ehrenberg ex Haeckel, Bukry, 1978a, p. 553, pl. 7, figs 9-17, pl. 8, figs. 1-10.

Remarks. See remarks following Bachmannocena paulschulzii.

\section{Bachmannocena paulschulzii Bukry}

(Plate 2, Fig. 8)

Mesocena oamaruensis var. quadrangula Schulz, 1928 (in part), p. 240 , fig. 12.

Mesocena occidentalis Hanna ex Bukry, 1977, p. 832.

Bachmannocena paulschulzii Bukry, 1987, p. 404.

Remarks. This species is recognized by its quadrate basal ring with straight sides and long spines. $B$. paulschulzii differs from $B$. quadrangula in having a more squarish ring with straight sides and generally longer spines. This species is sporadically abundant in the middle Eocene of Hole 748B.

A five-sided variant of this taxon was found in Sample 120-748B$13 \mathrm{H}-4,47-48 \mathrm{~cm}$.

\section{Genus CANNOPILUS Haeckel, 1887}

\section{Cannopilus antarcticus Ciesielski}

Cannopilus antarcticus Ciesielski, 1975, p. 654, pl. 1, figs. 1-9.

Remarks. A single specimen of this rare and elegant silicoflagellate was found in Sample 120-751A-15H-5, 10-11 cm. It was originally described from the lower Miocene of DSDP Leg 28.

\section{Genus CORBISEMA Hanna, 1928}

\section{Corbisema apiculata (Lemmermann)}

Dictyocha triacantha var. apiculata Lemmermann, 1901, p. 259, pl. 10, figs. 19 and 20

Corbisema apiculata (Lemmermann), Ling, 1972, p. 153, pl. 24, fig. 1; Shaw and Ciesielski, 1983, p. 706, pl. 1, figs. 1-3.

\section{Corbisema archangelskiana (Schulz) Frenguelli}

(Plate 1, Figs. 10-11)

Dictyocha triacantha var. archangelskiana Schulz, 1928, p. 250, figs. $33 \mathrm{a}-\mathrm{c}, 77$, and 78 .

Corbisema archangelskiana (Schulz), Martini and Müller, 1976, p. 869 , pl. 7, fig. 5 .

Remarks. This taxon was found sporadically in the upper Oligocene of Hole $747 \mathrm{~A}$ and the middle Eocene of Hole 748B. The specimens generally did not have spines. A four-sided specimen was found in Section 120-749B-2H-2 (see similar specimens in Shaw and Ciesielski, 1983, pl. 20).

\section{Corbisema bimucronata Deflandre}

Corbisema bimucronata Deflandre, 1950, p. 191, figs. 174-177.

Remarks. This taxon was observed only in Sample 120-749B9H-CC during shipboard study.

\section{Corbisema hastata (Lemmermann) Bukry}

Corbisema triacantha var. hastata Lemmermann, 1901, p. 259, pl. 10, figs. 16 and 17.

Corbisema hastata (Lemmermann), Ling, 1972, p. 155, fig. 5.

Remarks. Specimens of this taxon occur in the Naviculopsis trispinosa Zone (lower Oligocene) of Hole 748B.

\section{Corbisema triacantha (Ehrenberg) Hanna \\ (Plate 1, Fig. 12)}

Dictyocha triacantha Ehrenberg, 1844, p. 80.

Corbisema triacantha (Ehrenberg) Hanna, 1931, p. 198, pl. D, fig. 1.

\section{Genus DICTYOCHA Ehrenberg, 1839}

Dictyocha aspera (Lemmermann) Bukry and Foster s.l. (Plate 2, Figs. 6-7)

Dictyocha fibula var. aspera Lemmermann, 1901, p. 260, pl. 10, figs. 27 and 28.

Dictyocha aspera Bukry and Foster, 1973, p. 826, pl. 2, figs. 4 and 6.

Remarks. A broad species concept is used here as dictyochid morphologies with a minor-axis bridge were sparse.

\section{Dictyocha byronalis Bukry}

Dictyocha byronalis Bukry in Barron et al., 1984, p. 151, pl. 3, figs. $1-4$.

Remarks. This species was relatively abundant in Sample 120 $748 \mathrm{~B}-19 \mathrm{H}-3,47-48 \mathrm{~cm}$.

\section{Dictyocha defiandrei Frenguelli ex Glezer}

Dictyocha deflandrei Frenguelli, 1940 (in part), p. 65, figs. 14a, 14c, $14 \mathrm{f}$.

Dictyocha deflandrei Frenguelli ex Glezer, Bukry, 1975b, p. 854, pl. 2 , figs. 9-13.

Remarks. Two five-sided variants of this species were found in Sample 120-748B-13H-4, 47-48 cm.

\section{Dictyocha fibula Ehrenberg s.l.}

Dictyocha fibula Ehrenberg, 1839, fide Loeblich et al., 1968, p. 90, pl. 9, figs. 9-12.

Dictyocha fibula Ehrenberg, Bukry and Foster, 1973, pp. 826-827.

Remarks. A broad species concept is used here, as with Dictyocho aspera. Asperid and fibulid morphologies tended to be very similar and to occur together, indicating perhaps a closer biological relationship than the taxonomic separation would suggest.

Locker and Martini (1986) have determined from examination of Ehrenberg's original type specimens that the term Dictyocha fibula may best be applied to large specimens with an asperoid bar. Although it is difficult to argue against conclusions based on type material, it has been the general practice through nearly all of the silicoflagellate literature of this century to apply the "fibula" term to Dictyocha that have a "fibuloid" bridge, that is, one that is parallel to the major axis of the basal ring.

Silicoflagellates are extremely variable and there is uncertainty, at least by the authors of this paper, about whether fibuloid and asperoid morphologies represent separate and distinct species. These uncertainties have contributed to the broad species concept used herein for this taxon. Until the problems presented by dictyochid variability are better understood, we suggest that the conventional usage of $D$. fibula as having a bridge parallel to the major axis be retained, as least temporarily, as the application of $D$. fibula to asperoid morphologies will create much confusion. Thus, we continue this practice in this paper. 
Table 5. Abundance of silicoflagellates, Hole 751A.

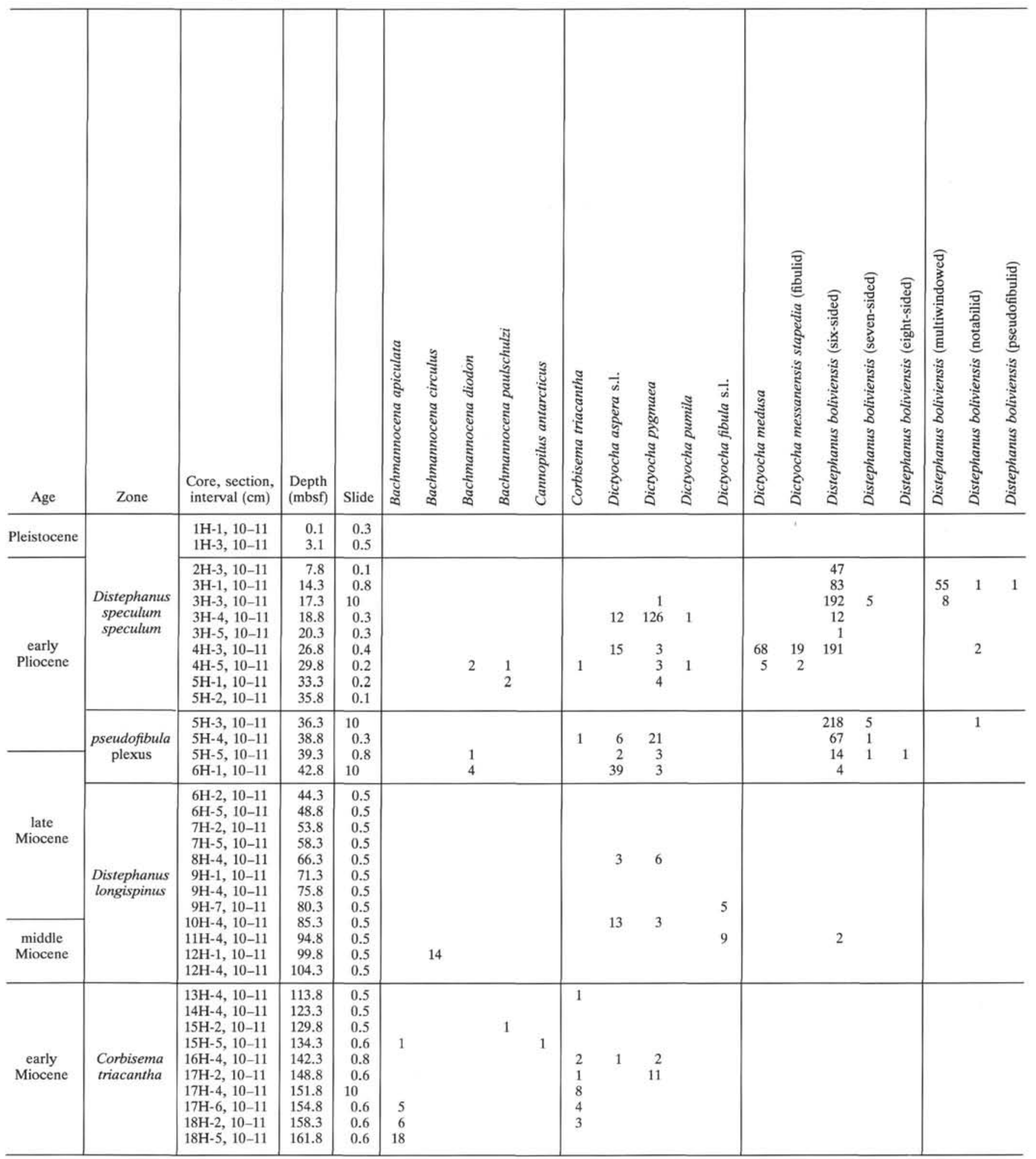


Table 5 (continued).

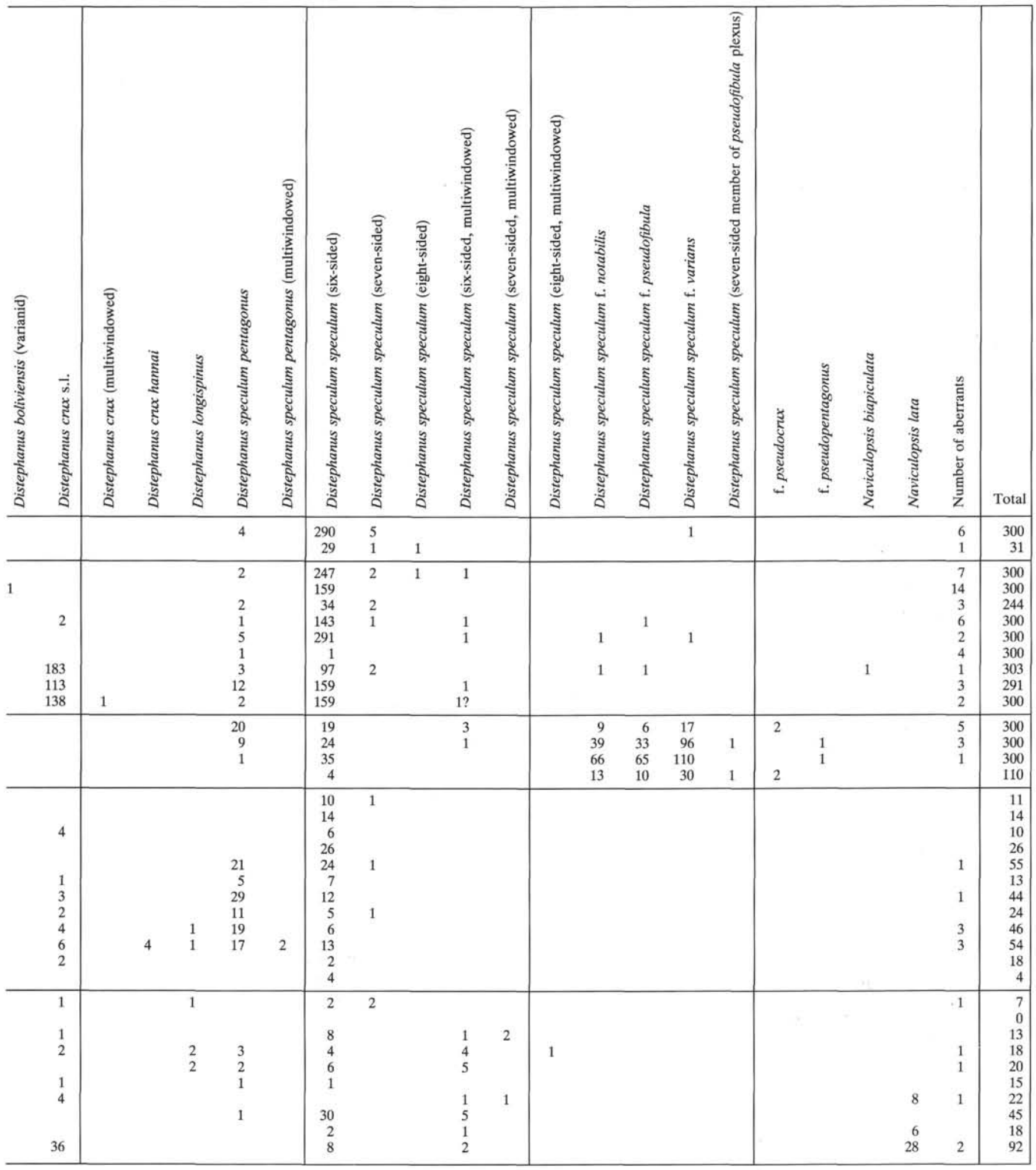

Note: Specimens are recorded as total number found for amount of $22 \times 50 \mathrm{~mm}$ slide examined. 


\section{Dictyocha frenguellii Deflandre}

Dictyocha frenguellii Deflandre, 1950, p. 194, figs. 188-193.

Remarks. See McCartney and Wise (1990) for a discussion on the phylogenetic relationship between this taxon and $D$. deflandrei.

Dictyocha grandis Ciesielski and Shaw

(Plate 3, Fig. 7; Plate 4, Figs. 1-2 and 5)

Dictyocha grandis Ciesielski and Shaw, in Shaw and Ciesielski, 1983, p. 711 , pl. 8 ; figs. 2 and $4-5$; pl. 9, figs. $1-4$; pl. 10, figs. 1-4.

Remarks. Shaw and Ciesielski (1983) noted the extreme variability of this unusually large silicoflagellate and reported at least nine $D$. grandis morphologies in DSDP Leg 71. Similar variation is found in this study, including six-sided pseudofibulid morphologies, five- and seven-sided morphologies, and multiwindowed configurations. Some specimens found in this study have a nearly round basal ring (Plate 4, Fig. 2), whereas others are polygonal. The close similarities in size and surface ornamentation between this group and D. stelliformis suggest that these have a close evolutionary relationship or are ecophenotypes. As noted by Ciesielski (1991), the first appearance of $D$. stelliformis appears to be below that of $D$. grandis. This species was also noted by Perch-Nielsen (1975) in Leg 29.

\section{Dictyocha medusa Haeckel}

Dictyocha medusa Haeckel, 1887, pl. 101, figs. 13 and 14.

Remarks. This is a rare morphology generally found in association with asperids and fibulids that have short bridges.

\section{Dictyocha messanensis stapedia (Haeckel) Locker and Martini} (Plate 2, Fig. 3)

Dictyocha stapedia Haeckel, 1887, pl. 101, figs. 10-15.

Dictyocha messanensis stapedia Haeckel, Locker and Martini, 1986, p. 904.

Dictyocha pentagona (Schulz) Bukry and Foster.

Dictyocha fibula var. pentagona Schulz, 1928, p. 255, fig. 41a.

Dictyocha pentagona (Schulz) Bukry and Foster, 1973, p. 827, pl. 3, fig. 10 .

Remarks. Specimens of this taxon found in Leg 120 samples appear to be dictyochid variants of Distephanus speculum pentagonus (or another distephanid taxon). Evidence supporting this includes the general rarity of this morphology and its similarities in size and spine length with co-occurring Distephanus speculum. Dictyochid morphologies that occur with this morphology are generally much larger. However, until a more detailed study is made, we consider it more convenient to retain the name with which it is usually known in literature, rather than recombining it as a subspecies of Distephanus speculum speculum. It is important to note that, although the fivesided dictyochid morphologies found in Leg 120 appear to be related to Distephanus speculum, similar morphologies found elsewhere may be related to Dictyocha species.

\section{Dictyocha pumila (Ciesielski) Bukry}

$$
\text { (Plate 2, Fig. 4) }
$$

Dictyocha fibula var. pumila Ciesielski, 1975, p. 656, pl. 5, figs. 5-10; pl. 6 , figs. 1 and 2 .

Dictyocha pumila (Ciesielski) Bukry, 1978c, p. 642.

Remarks. This interesting silicoflagellate, with its "sister" taxon Dictyocha aspera var. pygmaea, is an example of the taxonomic splitting that permeates the silicoflagellate literature. The two taxa are nearly identical in the size of the basal ring and the length of the spines, and co-occur in a narrow interval of the Pliocene. The only obvious difference between these taxa is in the alignment of the apical bridge with respect to the major or minor axis of the basal ring. The basal ring, however, is very close to being square; therefore, the assignment of the major axis is frequently difficult and highly subjective. Despite these similarities, which indicate variation within a population, the two slightly different morphologies have been described as variants of separate species, with these variants later elevated to new species.

The currently accepted names are retained for both morphologies, despite evidence that they are biologically conspecific. We prefer to work within the current silicoflagellate taxonomy as far as possible, rather than to further complicate the nomenclature with new combinations or emendations.

\section{Dictyocha pygmaea (Ciesielski) Shaw and Ciesielski}

Dictyocha aspera var. pygmaea, Ciesielski, 1975, p. 655 , pl. 4, figs. $1,3,4$, and 6 .

Remarks. See remarks for Dictyocha pumila.

\section{Dictyocha stelliformis Shaw and Ciesielski}

Dictyocha stelliformis Shaw and Ciesielski, 1983, p. 712, pl. 6, figs. 1-6.

Remarks. This species was first described from the Falkland Plateau and is characterized by its large size, quadrate or stellate basal ring, and massive apical spines with generally rounded terminations. The size, variability of the apical structure and basal corners, and the surface ornamentation are very similar to Dictyocha grandis, and we suspect they may represent ecophenotypic variants of a single species.

\section{Genus DISTEPHANUS Stohr, 1880}

\section{Distephanus boliviensis (Frenguelli) Bukry and Foster}

(Plate 3, Figs. 1 [top] and 2-3)

Dictyocha boliviensis Frenguelli, 1940 (in part), p. 44, figs. 4b-d.

Remarks. This taxon is distinguished from Distephanus speculum by being larger in size (see Plate 3, Fig. 1), although identification is not always easy. Both can have considerable variability, as best evidenced by the dictyochid variants of Distephanus speculum speculum. However, that these morphologies are polyphyletic is evidenced by the occurrence of variants of Ds. boliviensis with configurations similar to members of the "pseudofibula plexus" (McCartney and Wise, 1990). The dictyochid variants of Ds. boliviensis are not nearly as abundant as those found in the pseudofibula plexus.

Variants of Ds. boliviensis include all three morphologies common in the pseudofibula plexus (see McCartney and Wise, 1990). These are labeled in the species listings as varianid (in which three struts meet above the center of the basal plane), notabilid (which has an incomplete apical ring; Plate 4, Fig. 2), and pseudofibulid (which has an apical bridge from which struts attach to opposite sides of the basal ring; Plate 4, Fig. 3). These terms are also used for similar morphologies of Dictyocha grandis.

In addition to the pseudofibulid variants of Ds. boliviensis, members with seven or eight basal sides or multiwindowed apical structures were also found, although they are never abundant except in Sample $120-751 \mathrm{~A}-3 \mathrm{H}-1,10-11 \mathrm{~cm}$. In that sample, multiwindowed variants are common. The boliviensis variants are counted separately in the species listings.

\section{Distephanus crux (Ehrenberg) Haeckel}

Distephanus crux Ehrenberg, 1840, p. 207; Ehrenberg, 1854, pl. 18, fig. 56; pl. 33(XV), fig. 9.

Remarks. A multiwindowed specimen of this taxon was found in Sample 120-751A-5H-2, 10-11 cm.

\section{Distephanus crux hannai Bukry}

Distephanus crux hannai Bukry, 1975b, p. 855, pl. 4, figs. 4-6.

Remarks. This taxon is characterized by a small apical window. Four specimens were found in Sample 120-751A-11H-4, 10-11 cm. Because of close similarities between observed specimens of this taxon and co-occurring Ds. crux, we do not follow the elevation of this taxon to species rank as proposed by Bukry (1979).

\section{Distephanus longispinus (Schulz) Bukry and Foster (Plate 3, Fig. 4)}

Distephanus crux f. longispinus Schulz, 1928, p. 256, fig. 44. Distephanus longispinus (Schulz) Bukry and Foster, 1973, p. 828, pl. 4 , figs. 7 and 8.

Remarks. This taxon is used as a zonal indicator for the upper or middle Miocene, but its relative low abundance does not make it ideal 
for this purpose in southern high latitudes. In both this study and Leg 113, Ds. longispinus was a minor constituent and usually occurred less commonly than co-occurring $D s$. crux.

Specimens of Distephanus longispinus shared many similarities with co-occurring $D s$. crux, suggesting that the two may be conspecific, as originally believed by Schulz when he described the longspined morphology. A detailed numerical study of these taxa should be a worthwhile research project.

Distephanus polyactis polyactis (Ehrenberg) Deflandre

Distephanus polyactis Ehrenberg, 1854, pl. 22, fig. 50.

Distephanus polyactis polyactis (Ehrenberg), Ciesielski, 1975, p. 906 , pl. 5 , figs. 8 and 9 ).

Remarks. Three specimens of this unusual taxon were found in Sample 120-747A-7H-6, 47-48 cm. Two of these specimens had eight basal and apical sides whereas one specimen had ten sides.

\section{Distephanus raupii Bukry}

Distephanus raupii Bukry, Bukry, 1978b, p. 785, pl. 2, fig. 15.

Remarks. Specimens of this species are noticeably smaller than Ds. speculum, sometimes with basal diameters as small as $15 \mathrm{~mm}$. In Sample 120-748B-8H-6, in which Distephanus raupii is dominant, some of the four- and six-sided distephanid morphologies are of similar size, indicating a close relationship with Ds. raupii. (These specimens were tabulated as Ds. crux and Ds. speculum, respectively.) Multiwindowed morphologies are listed separately in the tables.

Distephanus speculum hemisphaericus (Ehrenberg) Bukry

Dictyocha hemisphaerica Ehrenberg, 1844, pl. 17, fig. 5.

Distephanus speculum hemisphaericus (Ehrenberg), Bukry, 1975a, p. 854; McCartney and Wise, 1990, pl. 4, figs. 1 and 3-7.

Remarks. Multiwindowed specimens closely similar to Ds. speculum speculum were frequently abundant in the Oligocene of Hole $748 \mathrm{~B}$.

Distephanus speculum pentagonus Lemmermann

Distephanus speculum var. pentagona Lemmermann, 1901, p. 264 , pl. 11, fig. 19.

Distephanus speculum pentagonus Lemmermann, Bukry, 1976a, p. 895; McCartney and Wise, 1990, pl. 3, figs. 6-8.

Distephanus speculum speculum (Ehrenberg) Glezer

(Plate 3, Fig. 1b; Plate 4, Fig. 3)

Dictyocha speculum Ehrenberg, 1840; Ehrenberg, 1854, pl. 18, fig. 57 ; pl. 19 , fig. 41 ; pl. 21 , fig. 44 ; pl. 22, fig. 47.

Distephanus speculum speculum $\mathrm{f}$. notabilis Locker and Martini (Plate 4, Fig. 5)

Distephanus speculum f. varians Gran and Braarud, 1935, p. 390, fig. $68 \mathrm{a}$.

Distephanus speculum varians Gran and Braarud, Bukry, 1976a, pl. 8, fig. 10.

Distephanus speculum speculum $\mathrm{f}$. notabilis McCartney and Wise, 1990, pl. 5, figs. 10-13; pl. 6, figs. 5 and 7.

Remarks. For a detailed discussion on members of the "pseudofibula plexus," see McCartney and Wise (1990).

Distephanus speculum speculum $\mathrm{f}$. pseudofibula Schulz (Plate 3, Fig. 6)

Distephanus speculum f. pseudofibula Schulz, 1928, p. 262, figs. 51a-b. Distephanus speculum speculum f. pseudofibula Schulz, McCartney and Wise, 1990, pl. 5, figs. 1-4; pl. 6, figs. 2-3.

Distephanus speculum speculum $\mathrm{f}$. varians Gran and Braarud (Plate 4, Fig. 4)

Distephanus speculum f. varians Gran and Braarud, 1935, p. 390, fig. $68 \mathrm{~b}$.

Distephanus speculum speculum $\mathrm{f}$. varians Gran and Braarud, McCartney and Wise, 1990, pl. 5, figs. 8-9 and 13a; pl. 6, figs. 4 and 6 .

Remarks. The varians form is generally the most common member of the pseudofibula plexus.

\section{Distephanus speculum speculum f. pseudocrux (Schulz) McCartney and Wise}

Distephanus speculum $\mathrm{f}$. pseudocrux Schulz, 1928, p. 263, figs. 52a-b. Distephanus speculum speculum f. pseudocrux (Schulz), McCartney and Wise, 1990, text figs. 6e-f.

\section{Distephanus speculum speculum f. pseudopentagonus McCartney and Wise}

Distephanus speculum speculum $\mathrm{f}$. pseudopentagonus McCartney and Wise, 1990, pl. 5, fig. 6.

Genus LYRAMULA Hanna, 1928

\section{Lyramula furcula Hanna}

Lyramula furcula Hanna, 1928, p. 262, pl. 41, figs. 4 and 5.

Remarks. Reworked specimens of this Cretaceous silicoflagellate were found in Samples 120-749B-5H-4, 110-112 cm, and 120-748B$18 \mathrm{H}-7,47-48 \mathrm{~cm}$.

\section{Genus NAVICULOPSIS Frenguelli, 1940}

\section{Naviculopsis biapiculata (Lemmermann) Frenguelli} (Plate 1, Figs. 3 and 7-8)

Dictyocha navicula biapiculata Lemmermann, 1901, p. 258, pl. 10, figs. 14-15.

Naviculopsis biapiculata (Lemmermann) s.l., Dumitrica, 1973 (in part), p. 847, pl. 1, fig. 4 .

Naviculopsis biapiculata (Lemmermann), Bukry, 1978b, p. 787, pl. 3, figs. 9 and 10.

Remarks. The basal ring of this taxon has a low aspect ratio, and spines that are approximately the same length, or a little shorter, than the length of the basal ring. The apical bar is highly arched and in some cases appears to have a spine. The taxon co-occurs with $N$. trispinosa, which has a similar basal ring and spine dimensions. Thus, $N$. biapiculata and $N$. trispinosa appear to be very closely related. $N$. biapiculata is sometimes dominant in the middle Eocene of Hole 748B and is also found in the lower and upper Oligocene of Hole 749B, in which it has an apical ring that is slightly more elongate and an apical ring that is less arched than members of that taxon found in Hole $748 \mathrm{~B}$.

A reworked specimen of this taxon was found in Sample 120$751 \mathrm{~A}-5 \mathrm{H}-4,10-11 \mathrm{~cm}$.

\section{Naviculopsis constricta (Schulz) Frenguelli} (Plate 1, Fig. 5)

Dictyocha navicula biapiculata constricta Schulz, 1928, p. 246, fig. 21.

Naviculopsis constricta (Schulz), Bukry, 1975b, p. 856; Shaw and Ciesielski, 1983, p. 714 , pl. 15, figs. 4-8.

\section{Naviculopsis eobiapiculata Bukry}

(Plate 1, Figs. 2 and 4)

Naviculopsis eobiapiculata Bukry, 1978b, p. 787.

Remarks. Naviculopsis eobiapiculata is distinguished from $N$. biapiculata by having a longer basal aspect ratio and usually longer spines. It occurs in association with $N$. biapiculata in the lower and upper Oligocene of Hole 749B.

\section{Naviculopsis foliacea Deflandre}

Naviculopsis foliacea Deflandre, 1950, p. 204, figs. 235-240; Shaw and Ciesielski, 1983, p. 715, pl. 16, figs. 1-7, 10, and 12 .

Remarks. Naviculopsis foliacea is generally similar to $N$. constricta, but it has a wider apical plate (see McCartney and Wise, 1987, for an illustration).

\section{Naviculopsis lata (Deflandre) Frenguelli} (Plate 1, Fig. 1)

Dictyocha biapiculata var. lata Deflandre, 1932, p. 500, figs. 30-31. Naviculopsis lata (Deflandre) Frenguelli, 1940, p. 61, fig. 11h. Naviculopsis lata (Deflandre), Bukry, 1982, p. 431, pl. 7, figs. 11-14. 

751A.

Remarks. Naviculopsis lata is found in the lower Miocene of Hole

\section{Naviculopsis trispinosa (Schulz) Glezer}

(Plate 1, Fig. 6)

Dictyocha navicula trispinosa Schulz, 1928, p. 246, figs. 23a-b.

Naviculopsis trispinosa (Schulz), Bukry, 1975b, p. 857, pl. 7, figs. 5-7.

Remarks. Naviculopsis trispinosa occurs in the middle Eocene intervals of Holes 748B and 749B in association with $N$. biapiculata that have highly arched apical bars.

\section{ACKNOWLEDGMENTS}

We thank Sherwood W. Wise, Jr., for encouragement and use of the facilities at Florida State University and USSAC for grant support for sample preparation. Richard Graham, Mark Izold, Rick Jacko, and Mathew Karrer provided essential technical assistance. This study is partly supported by a professional development grant from the University of Maine at Presque Isle.

\section{REFERENCES}

Barron, J. A., Bukry, D., and Poore, R. Z., 1984. Correlation of the middle Eocene Kellogg Shale of northern California. Micropaleontology, 30:138-170.

Bukry, D., 1973. Coccolith and silicoflagellate stratigraphy, Deep Sea Drilling Project Leg 18, eastern North Pacific. In Kulm, L. D., von Huene, R., et al., Init. Repts. DSDP, 18: Washington (U.S. Govt. Printing Office), 817-831.

1975a. Coccolith and silicoflagellate stratigraphy near Antarctica, Deep Sea Drilling Project, Leg 28. In Hayes, D. E., Frakes, L. A., et al., Init. Repts. DSDP, 28: Washington (U.S. Govt. Printing Office), 709-723.

,1975b. Silicoflagellate and coccolith stratigraphy, Deep Sea Drilling Project Leg 29. In Kennett, J. P., Houtz, R. E., et al., Init. Repts. DSDP, 29: Washington (U.S. Govt. Printing Office), $845-$ 872.

1976a. Cenozoic silicoflagellate and coccolith stratigraphy, South Atlantic Ocean, Deep Sea Drilling Project Leg 35. In Hollister, C. D., Craddock, C., et al., Init. Repts. DSDP, 35: Washington (U.S. Govt. Printing Office), 885-917.

1976b. Comments on some coccoliths and silicoflagellates from Deep Sea Drilling Project Leg 35. In Hollister, C. D., Craddock, C., et al., Init. Repts. DSDP, 35: Washington (U.S. Govt. Printing Office), 693-699.

1977. Coccolith and silicoflagellate stratigraphy, South Atlantic Ocean, Deep Sea Drilling Project Leg 39. In PerchNielsen, K., Supko, P. R., et al., Init. Repts. DSDP, 39: Washington (U.S. Govt. Printing Office), 825-840.

1978a. Cenozoic coccolith, silicoflagellate, and diatom stratigraphy, Deep Sea Drilling Project Leg 44. In Benson, W. E., Sheridan, R. E., et al., Init. Repts. DSDP, 44: Washington (U. S. Govt. Printing Office), 807-860.

1978b. Cenozoic silicoflagellate and coccolith stratigraphy, northwestern Atlantic Ocean, Deep Sea Drilling Leg 43. In Benson, W. E., Sheridan, R. E., et al., Init. Repts. DSDP, 44: Washington (U. S. Govt. Printing Office), 775-805.

1978c. Cenozoic silicoflagellate and coccolith stratigraphy, southeastern Atlantic Ocean, Deep Sea Drilling Project Leg 40. In Bolli, H. M., Ryan, W.B.F., et al., Init. Repts. DSDP, 40: Washington (U.S. Govt. Printing Office), 635-649.

1979. Coccolith and silicoflagellate stratigraphy, northern Mid-Atlantic Ridge and Reykjanes Ridge, Deep Sea Drilling Project Leg 49. In Luyendyk, B. P., Cann, J. R., et al., Init. Repts. DSDP, 49: Washington (U. S. Govt. Printing Office), 551-581.

1981. Silicoflagellate stratigraphy of offshore California and Baja California, Deep Sea Drilling Project Leg 63. In Yeats, R. S., Haq, B. u., et al., Init. Repts DSDP, 63: Washington (U.S. Govt. Printing Office), 539-557.

1982. Cenozoic silicoflagellates from offshore Guatemala, Deep Sea Drilling Project Site 495. In Aubouin, J., von Huene, R., et al., Init. Repts DSDP, 67: Washington (U.S. Govt. Printing Office), $425-445$.
1987. Eocene siliceous and calcareous phytoplankton, Deep Sea Drilling Project Leg 95. In Poag, C. W., Watts, A. B., et al., Init. Repts. DSDP, 95: Washington (U.S. Govt. Printing Office), 395-415.

1991. Oligocene and Quaternary silicoflagellates from the Kerguelen Plateau. In Barron, J., Larsen, B., et al., Proc. ODP, Sci. Results, 119: College Station, TX (Ocean Drilling Program), $\mathrm{XXX}-\mathrm{XXX}$.

Bukry, D., and Foster, J. H., 1973. Silicoflagellate and diatom stratigraphy, Leg 16, Deep Sea Drilling Project. In van Andel, T. H., Heath, G. R., et al., Init. Repts. DSDP, 16: Washington (U.S. Govt. Printing Office), 815-871.

Busen, K. E., and Wise, S. W., Jr., 1977. Silicoflagellate stratigraphy, Deep Sea Drilling Project, Leg 36. In Barker, P., Dalziel, I.W.D., et al., Init. Repts. DSDP, 36: Washington (U.S. Govt. Printing Office), 697-743.

Ciesielski, P. F., 1975. Biostratigraphy and paleoecology of Neogene and Oligocene silicoflagellates from cores recovered during Antarctic Leg 28, Deep Sea Drilling Project. In Hayes, D. E., Frakes, L. A., et al., Init. Repts. DSDP, 28: Washington (U.S. Govt. Printing Office), 625-691.

1991. Biostratigraphy of diverse silicoflagellate assemblages from the early Paleocene to early Miocene of Holes 698A, 700B, 702B, and 703A: subantarctic South Atlantic. In Ciesielski, P. F., Kristoffersen, Y., et al., Proc. ODP, Sci. Results, 114: College Station, TX (Ocean Drilling Program), 49-96.

Ciesielski, P. R., and Weaver, F. M., 1974. Early Pliocene temperature changes in the Antarctic Seas. Geology, 12:511-515.

Deflandre, G., 1932. Sur la systématique des silicoflagellidés. Bull. Soc. Bot. Fr., 79:494-506.

1950. Contribution a l'étude des silicoflagellidés actuels et fossiles. Microscopie, 2:72-108, 117-142, 191-210.

Dumitrica, P., 1973. Paleocene, late Oligocene and post-Oligocene silicoflagellates in southwestern Pacific sediments cored on DSDP Leg 21. In Burns, R. E., Andrews, J. E., et al., Init. Repts DSDP, 21: Washington (U.S. Govt. Printing Office), 837-883.

Ehrenberg, C. G., 1839. Über die Bildung der Kreidefelsen und des Kreidemergels durch unsichtbare Organismem. K. Preuss. Akad. Wiss. Berlin Ber., 1838:59-148.

1840. 274 Blatter von ihm selbst augefuhrter Zeichnungen von ebenso vielen Arten. K. Preuss. Akad. Wiss. Berlin Ber., 1840:197-219.

1844. Mittheilung uber zwei neue Lager von Gebirgsmassen aus Infusorien als Meeres-Absatz in Nord-Amerika und eine Vergleichung derselben mit den organischen Kreide-Gebilden in Europa und Afrika. K. Preuss. Akad. Wiss. Berlin Ber., 1844:5797.

1954. Mikrogeologie: Leipzig (Leopold Voss).

Frenguelli, J., 1940. Consideraciones sobre los silicoflagelades fossiles. Rev. Mus. La Plata, Secc. Geol., Ser. 2, 2:37-112.

Gran, H. H., and Braarud, T., 1935. A quantitative study of the phytoplankton in the Bay of Fundy and the Gulf of Maine (including observations of the hydrogeology, chemistry and turbidity). J. Biol. Board Can., 1:279-467.

Haeckel, E., 1887. Report on the Radiolaria collected by H.M.S. Challenger during the years 1873-1876. Rep. Sci. Results Voy. H.M.S. Challenger, Zool., 18:1-1803.

Hajós, M., and Stradner, H., 1975. Late Cretaceous archaeomonadaceae, diatomaceae, and silicoflagellatae from the South Pacific Ocean, Deep Sea Drilling Project, Leg 29, Site 275. In Kennett, J. P., Houtz, R. E., et al., Init. Repts. DSDP, 29: Washington (U.S. Govt. Printing Office), 913-1009.

Hanna, G. D. 1928. Silicoflagellata from the Cretaceous of California. J. Paleontol., 1:259-263.

1931. Diatoms and silicoflagellates of the Kreyenhagen shale. Calif. Div. Mines Geol. State Mineral. Rep., 27:187-201.

Haq, B. U., and Riley, A., 1976. Antarctic silicoflagellates from the southeast Pacific, Deep Sea Drilling Project Leg 35. In Hollister, C. D., Craddock, C., et al., Init. Repts. DSDP, 35: Washington (U.S. Govt. Printing Office), 673-691.

Harwood, D. M., 1986. Diatom biostratigraphy and paleoecology with a Cenozoic history of Antarctic ice sheets [Ph.D. dissert.]. Ohio State Univ., Columbus. 
1988. Upper Cretaceous and lower Paleocene diatom and silicoflagellate biostratigraphy of Seymour Island, eastern Antarctic Peninsula. In Feldman, R. M., and Woodburne, M. O. (Eds.), Seymour Island Geology and Paleontology. Mem. Geol. Soc. Am., 169:55-129.

1989. Siliceous microfossils. In Barrett, P. J. (Ed.), Antarctic Cenozoic History from the CIROS-1 Drillhole, McMurdo Sound. DSIR Bull. N.Z., 245:67-97.

Harwood, D. M., Scherer, R. P., and Webb, P.-N., 1989. Multiple Miocene marine productivity events in West Antarctica as recorded in upper Miocene sediments beneath the Ross Ice Shelf (Site J-9). Mar. Micropaleontol., 15:91-115.

Lemmermann, E., 1901. Silicoflagellatae. Dtsch. Bot. Ges. Ber., 19:247-271.

Ling, H. Y., 1972. Upper Cretaceous and Cenozoic silicoflagellates and ebridians. Bull. Am. Paleontol., 62:135-229.

Ling, H. Y., and White, R. J., 1979. Silicoflagellate Mesocena pappii identified in R.I.S.P. Site J-9 core sediments. Antarct. J. U.S., 14:126-127.

Locker, S., and Martini, E., 1986. Silicoflagellates and some sponge spicules from the southwest Pacific, Deep Sea Drilling Project, Leg 90. In Kennett, J. P., von der Borch, C. C., et al., Init. Repts. DSDP, 90: Washington (U.S. Govt. Printing Office), 887-924.

Loeblich, A., III, Loeblich, L. A., Tappan, H., and Loeblich, A. R., Jr., 1968. Annotated index of fossil and recent silicoflagellates and ebridians with descriptions and illustrations of validly proposed taxa. Mem. Geol. Soc. Am., 106:1-319.

Martini, E., 1971. Neogene silicoflagellates from the equatorial Pacific. In Winterer, E. L., Riedel, W. R., et al., Init. Repts. DSDP, 7 (Pt. 2): Washington (U.S. Govt. Printing Office), 1695-1708.

Martini, E., and Müller, C., 1976. Eocene to Pleistocene silicoflagellates from the Norwegian-Greenland Sea (DSDP Leg 38). In Talwani, M., Udintsev, G., et al., Init. Repts. DSDP, 38: Washington (U.S. Govt. Printing Office), 857-895.

McCartney, K., and Loper, D. E., 1989. Mathematical modeling of silicoflagellate genera Dictyocha and Distephanus. Paleobiology, 15:283-298.
McCartney, K., and Wise, S. W., Jr., 1987. Silicoflagellates and ebridians from Deep Sea Drilling Project Leg 93, Site 604 and 605 (New Jersey Transect). In van Hinte, J. E., Wise, S. W., Jr., et al., Init. Repts. DSDP, 93 (Pt. 2): Washington (U.S. Govt. Printing Office), 801-814.

1990. Cenozoic silicoflagellates and ebridians from ODP Leg 113: biostratigraphy and notes on morphologic variability. In Barker, P. F., Kennett, J. P., et al., Proc. ODP, Sci. Results, 113: College Station, TX (Ocean Drilling Program), 729-760.

Perch-Nielsen, K., 1975. Late Cretaceous to Pleistocene silicoflagellates from the southern southwest Pacific, DSDP Leg 29. In Kennett, J. P., Houtz, R. E., et al., Init. Repts. DSDP, 29: Washington (U.S. Govt. Printing Office), 677-721.

Pichon, J. J., Labracherie, M., Labeyrie, L. D., and Duprat, J., 1987. Transfer functions between diatom assemblages and surface hydrology in the Southern Ocean. Palaeogeogr., Palaeoclimatol., Palaeoecol., 61:79-95.

Schulz, P., 1928. Beiträge zur Kenntnis fossiler und rezenter Silicoflagellaten. Bot. Arch., 21:225-292.

Shaw, C. A., and Ciesielski, P. F., 1983. Silicoflagellate biostratigraphy of middle Eocene to Holocene subantarctic sediments recovered by Deep Sea Drilling Project Leg 71. In Ludwig, W. J., Krasheninnikov, V. A., et al., Init. Repts. DSDP, 71 (Pt. 2): Washington (U.S. Govt. Printing Office), 687-737.

White, R. J., 1980. Southern Ocean silicoflagellate and ebridian biostratigraphy, the opening of the Drake Passage, and the Miocene of the Ross Sea, Antarctica [M.S. thesis]. Northern Illinois Univ., DeKalb.

Date of initial receipt: 5 March 1990

Date of acceptance: 24 November 1990

Ms 120B-154 

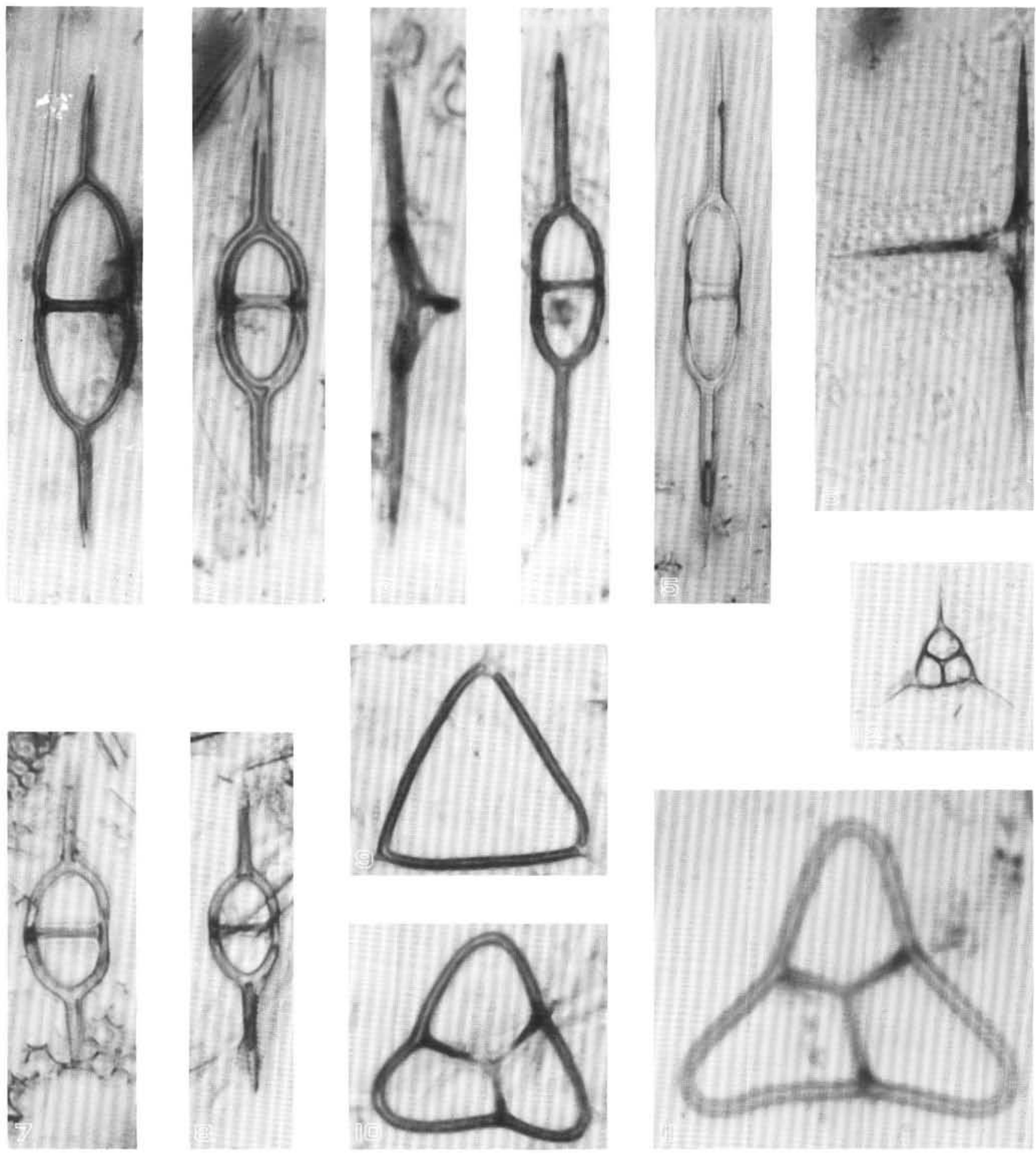

Plate 1. Silicoflagellates from Leg 120 (magnification $\times 520$ ). 1. Naviculopsis lata (Deflandre), Sample 120-751A-17H-4, 10-11 cm. 2 . Naviculopsis eobiapiculata Bukry, Sample 120-749B-1H-1, 10-11 cm. 3. Naviculopsis biapiculata (Lemmermann), Sample 120-748B$11 \mathrm{H}-2,10-11 \mathrm{~cm}$. 4. Naviculopsis eobiapiculata Bukry, Sample 120-749B-2H-5, 10-11 cm. 5. Naviculopsis constricta (Schulz), Sample 120-748B-18H-6, 10-11 cm. 6. Naviculopsis trispinosa (Schulz), Sample 120-748B-13H-4, 10-11 cm. 7-8. Naviculopsis biapiculata (Lemmermann); (7) Sample 120-748B-8H-6, 10-11 cm; (8) Sample 120-751A-4H-5, 10-11 cm. 9. Bachmannocena apiculata (Schulz), Sample 120-748B-13H-4, 10-11 cm. 10-11. Corbisema archangelskiana (Schulz); (10) Sample 120-748B-11H-2, 10-11 cm; (11) Sample 120-748B-9H-4, 10-11 cm. 12. Corbisema triacantha (Ehrenberg), Sample 120-751A-4H-5, 10-11 cm. 

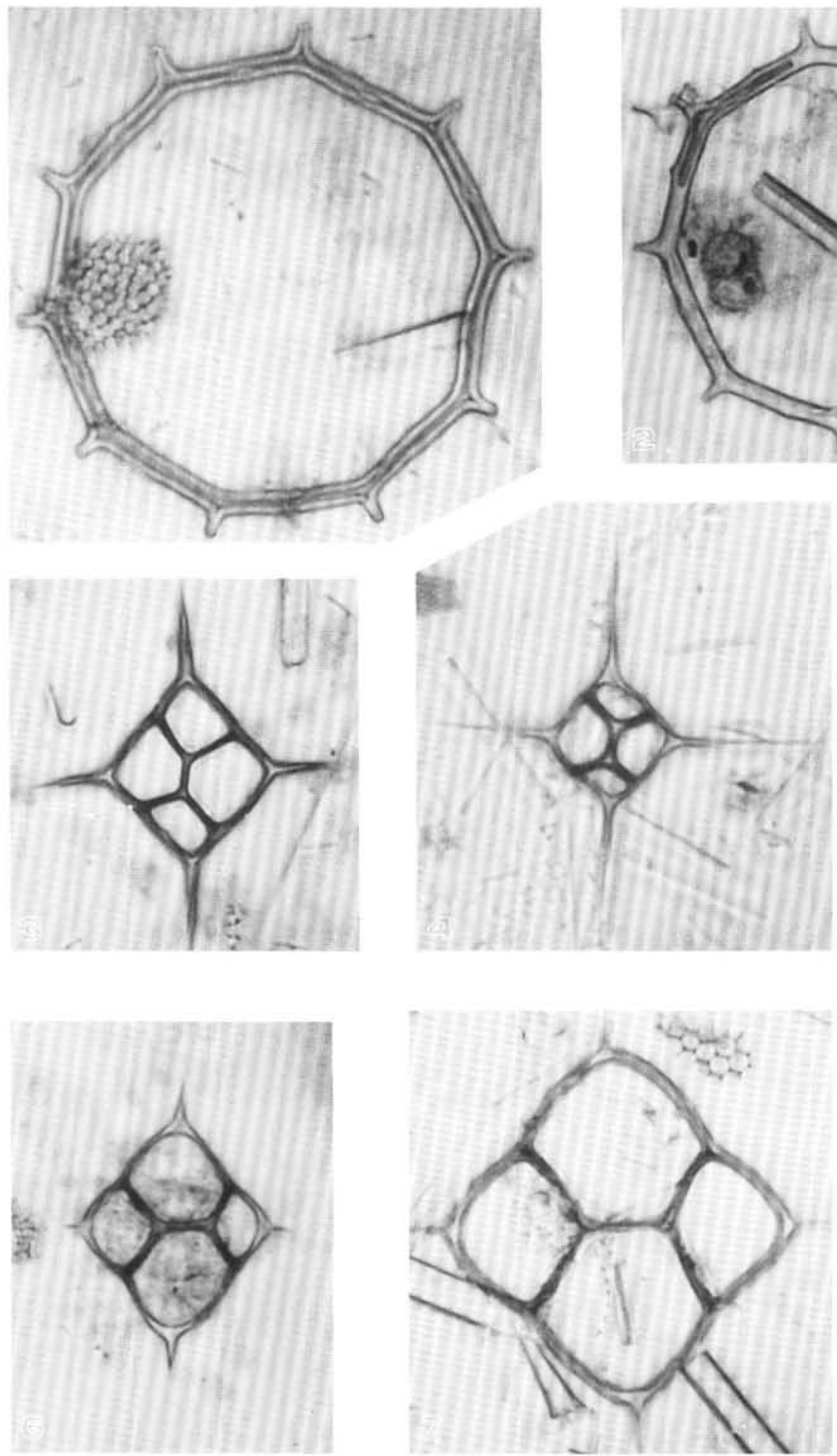
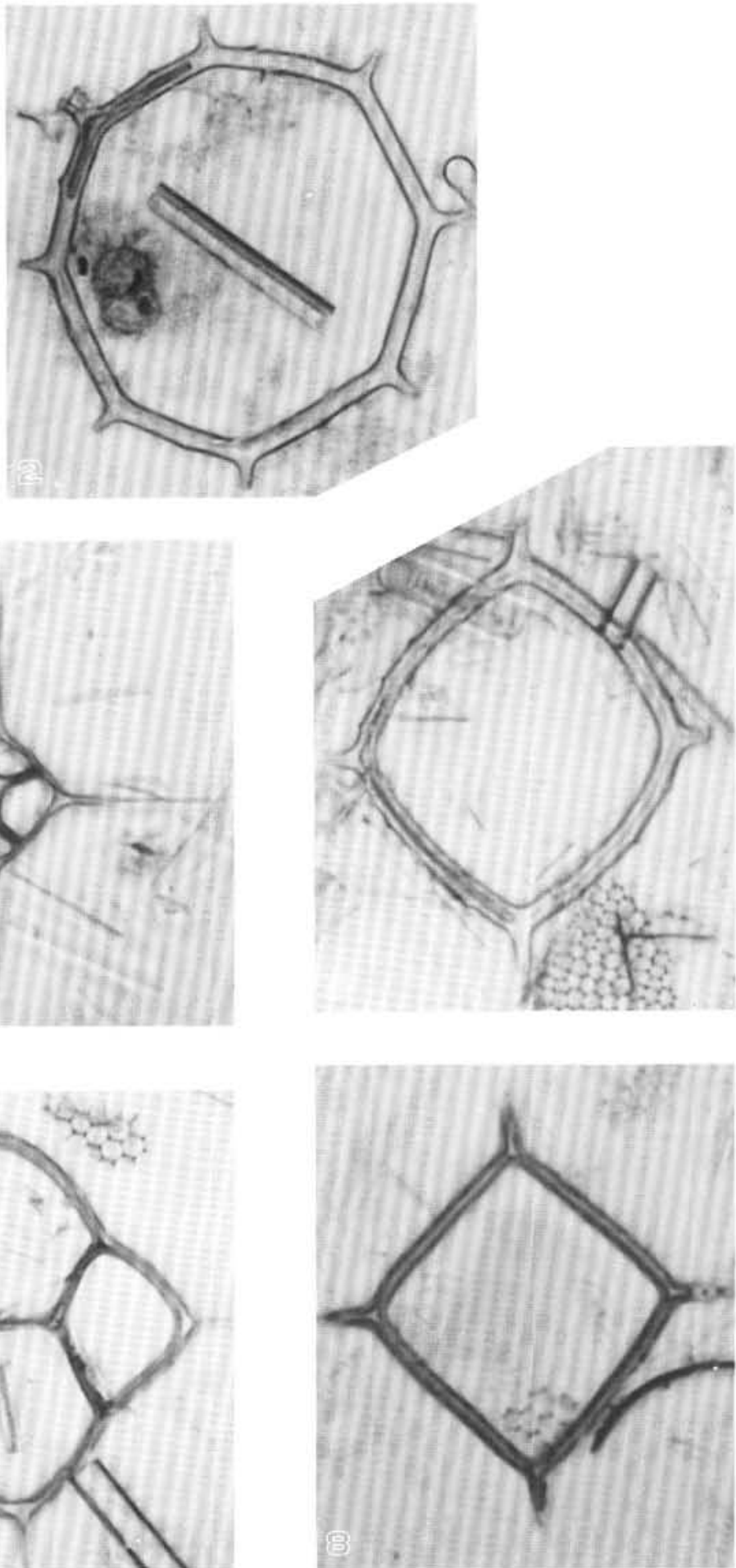

Plate 2. Silicoflagellates from Leg 120 (magnification $\times 520$ ). 1-2. Bachmannocena circulus (Ehrenberg), Sample 120-751A-12H-1, 10-11 cm. 3. Dictyocha messanensis stapedia (Haeckel), Sample 120-751A-11H-4, 10-11 cm. 4. Dictyocha fibula var. pumila Ciesielski, Sample 120-751A-4H-3, 10-11 cm. 5. Bachmannocena quadrangula Ehrenberg ex Haeckel, Sample 120-751A-4H-5, 10-11 cm. 6-7. Dictyocha aspera (Lemmermann) s.l.; (6) Sample 120-751A-5H-5, 10-11 cm; (7) Sample 120-751A-4H-3, 10-11 cm. 8. Bachmannocena paulschulzii Bukry, Sample 120-748B-13H-4, 10-11 cm. 

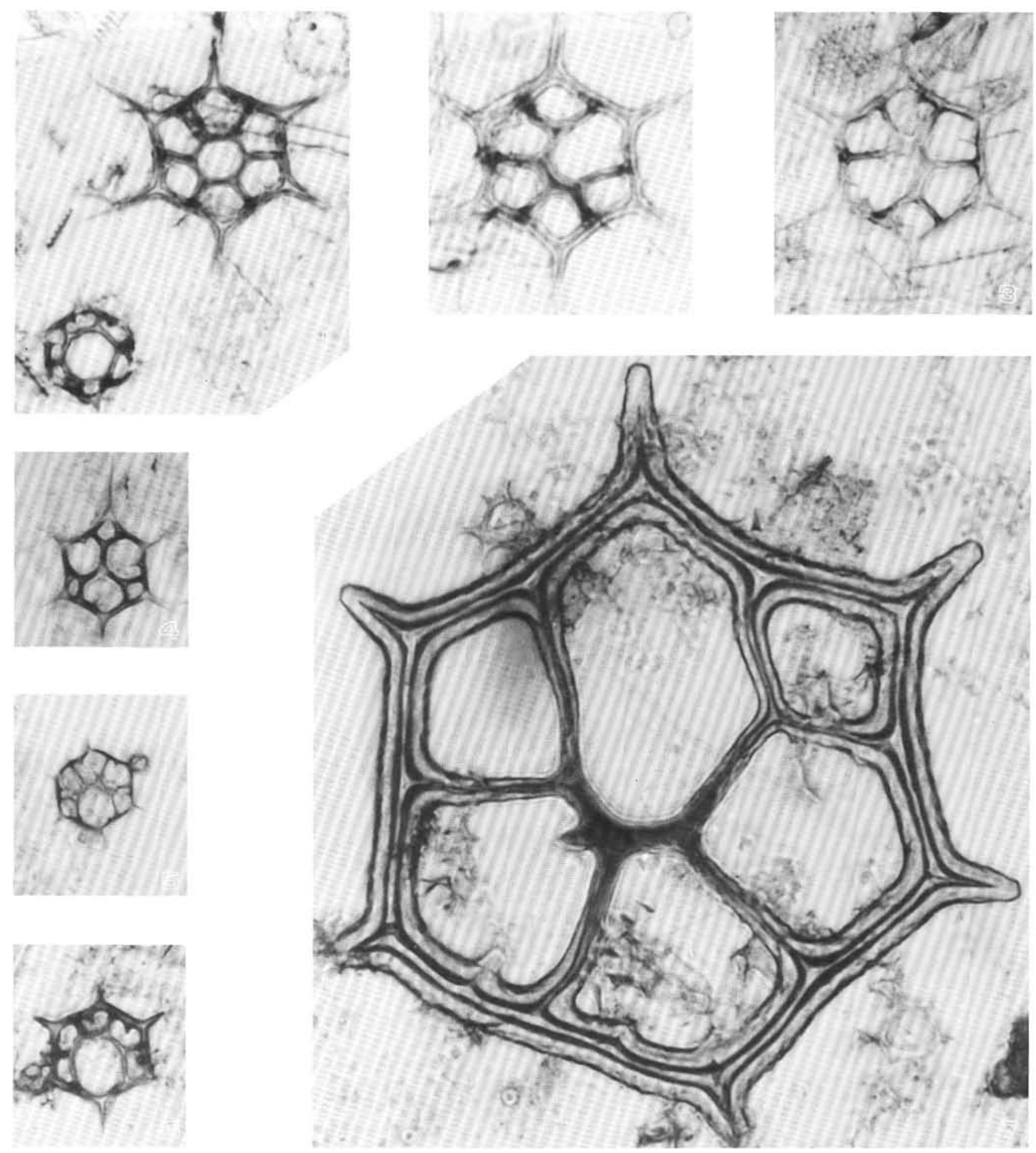

Plate 3. Silicoflagellates from Leg 120 (magnification $\times 520$ ). 1. Distephanus boliviensis (top) and Distephanus speculum speculum (bottom), Sample 120-751A-2H-3, 10-11 cm. 2-3. Distephanus boliviensis Frenguelli; (2) notabilid, Sample 120-751A-4H-3, 10-11 cm; (3) pseudofibulid, Sample 120-751A-3H-1, 47-48 cm. 4. Distephanus speculum speculum f. varians Gran and Braarud, Sample 120-751A-5H-5, 10-11 cm. 5-6. Distephanus speculum speculum f. notabilis Locker and Martini; (5) Sample 120-751A-6H-1, 10-11 cm; (6) Sample 120-751A-6H-1, 10-11 cm. 7. Dictyocha grandis Ciesielski and Shaw, notabilid, Sample 120-748B-18H-7, 10-11 cm. 


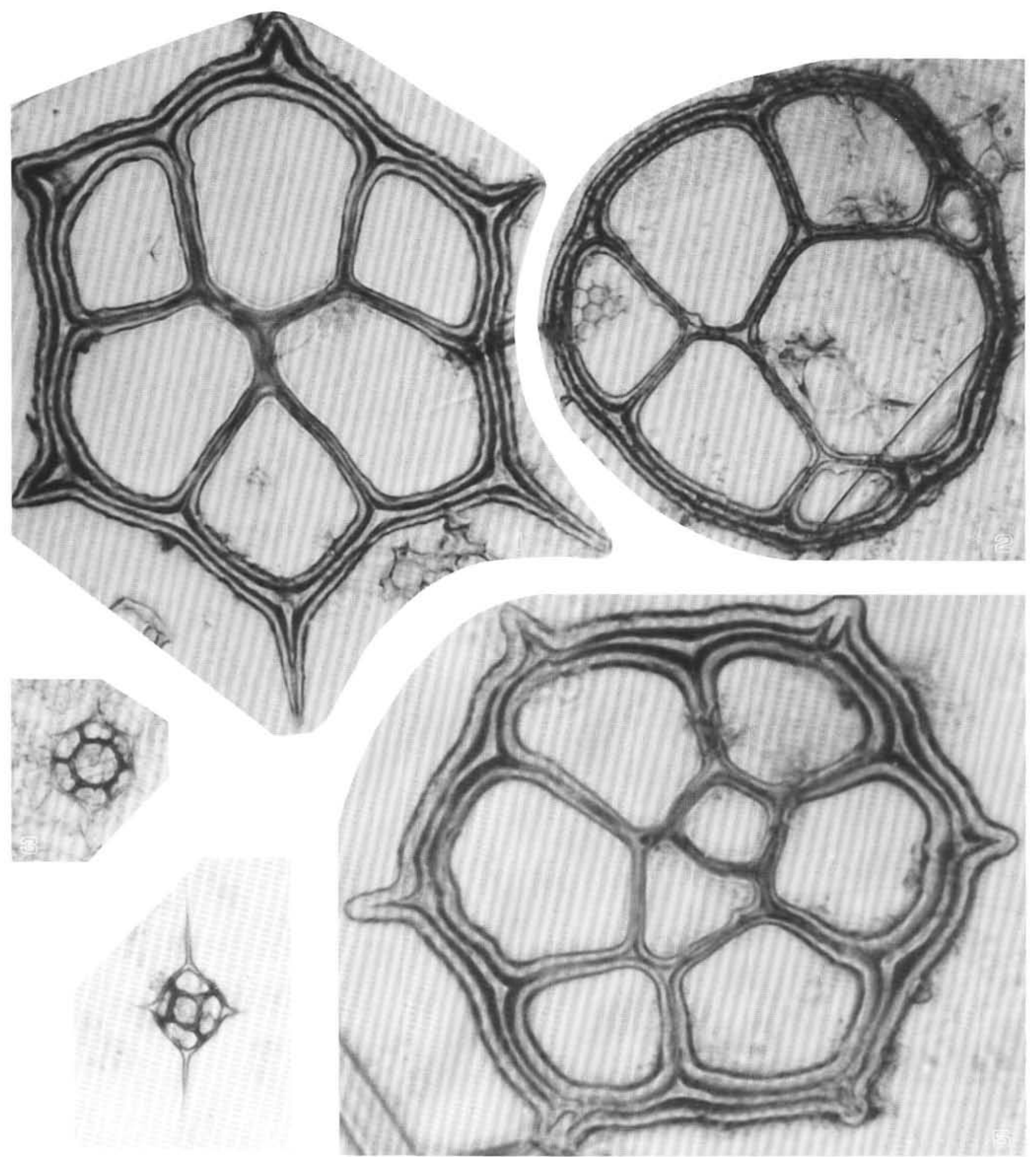

Plate 4. Silicoflagellates from Leg 120 (magnification $\times 520$ ). 1-2. Dictyocha grandis Ciesielski and Shaw; (1) varianid, Sample 120-748B$18 \mathrm{H}-6,10-11 \mathrm{~cm}$; (2) seven-sided, Sample 120-748B-19H-3, 10-11 cm. 3. Distephanus speculum speculum (Ehrenberg), Sample 120-751A$5 \mathrm{H}-4,10-11 \mathrm{~cm}$. 4. Distephanus longispinus (Schulz), Sample 120-751A-12H-1, 10-11 cm. 5. Dictyocha grandis Ciesielski and Shaw, multiwindowed, Sample 120-749B-9H-1, 10-11 cm. 